\title{
G Protein-Coupled Estrogen Receptor Protects From Angiotensin II-Induced Increases in Pulse Pressure and Oxidative Stress
}

\section{OPEN ACCESS}

Edited by:

Georgios Kararigas, Charité - Universitätsmedizin

Berlin, Germany

Reviewed by:

Tommaso Angelone, University of Calabria, Italy

Roger Lyrio Santos,

Federal University of Espirito

Santo, Brazil

*Correspondence:

Sarah H. Lindsey

lindsey@tulane.edu

Specialty section: This article was submitted to Molecular and Structural Endocrinology,

a section of the journal Frontiers in Endocrinology

Received: 09 May 2019 Accepted: 09 August 2019 Published: 27 August 2019

Citation:

Ogola BO, Zimmerman MA, Sure VN Gentry KM, Duong JL, Clark GL, Miller KS, Katakam PVG and Lindsey SH (2019) G Protein-Coupled Estrogen Receptor Protects From Angiotensin II-Induced Increases in Pulse Pressure and Oxidative Stress. Front. Endocrinol. 10:586 doi: 10.3389/fendo.2019.00586

\begin{abstract}
Benard O. Ogola ${ }^{1}$, Margaret A. Zimmerman ${ }^{1}$, Venkata N. Sure ${ }^{1}$, Kaylee M. Gentry ${ }^{1}$, Jennifer L. Duong ${ }^{1}$, Gabrielle L. Clark ${ }^{2}$, Kristin S. Miller ${ }^{2}$, Prasad V. G. Katakam ${ }^{1}$ and Sarah H. Lindsey ${ }^{1 *}$

'Department of Pharmacology, Tulane University, New Orleans, LA, United States, ${ }^{2}$ Department of Biomedical Engineering, Tulane University, New Orleans, LA, United States
\end{abstract}

Our previous work showed that the G protein-coupled estrogen receptor (GPER) is protective in the vasculature and kidneys during angiotensin (Ang) II-dependent hypertension by inhibiting oxidative stress. The goal of the current study was to assess the impact of GPER deletion on sex differences in Ang II-induced hypertension and oxidative stress. Male and female wildtype and GPER knockout mice were implanted with radiotelemetry probes for measurement of baseline blood pressure before infusion of Ang II (700 ng/kg/min) for 2 weeks. Mean arterial pressure was increased to the same extent in all groups, but female wildtype mice were protected from Ang II-induced increases in pulse pressure, aortic wall thickness, and Nox4 mRNA. In vitro studies using vascular smooth muscle cells found that pre-treatment with the GPER agonist G-1 inhibited Ang II-induced ROS and NADP/NADPH. Ang II increased while G-1 decreased Nox4 mRNA and protein. The effects of Ang II were blocked by losartan and Nox4 siRNA, while the effects of G-1 were inhibited by adenylyl cyclase inhibition and mimicked by phosphodiesterase inhibition. We conclude that during conditions of elevated Ang II, GPER via the CAMP pathway suppresses Nox4 transcription to limit ROS production and prevent arterial stiffening. Taken together with our previous work, this study provides insight into how acute estrogen signaling via GPER provides cardiovascular protection during Ang II hypertension and potentially other diseases characterized by increased oxidative stress.

Keywords: estrogen, G protein-coupled estrogen receptor, NADPH oxidase 4, oxidative stress, cell signaling/signal transduction

\section{INTRODUCTION}

Premenopausal women are protected from cardiovascular disease compared with age-matched men, while aging narrows this sex difference (1). The G protein-coupled estrogen receptor (GPER), previously known as GPR30, mediates non-genomic signaling by estrogen and is expressed in vascular endothelial and smooth muscle cells (2-4). Numerous ligands bind to GPER such as estradiol (3), 2-methoxyestradiol (5), genistein (6), and the selective agonist G-1 (7). We previously showed that G-1 induces vasorelaxation by inducing nitric oxide release from endothelial cells and increasing cAMP signaling in smooth muscle cells (8). Pharmacological activation of GPER 
ameliorates maladaptive tissue remodeling in the vasculature, heart, and kidneys of salt-sensitive mRen2 female rats (9-11), as well in doxorubicin-induced cardiotoxicity (12). Global GPER deletion does not impact reproductive function yet induces a variety of cardiometabolic deficits (13) including increased fat mass $(14,15)$, atherosclerosis (16), blood pressure, and glucose intolerance (17). Moreover, the first study to conditionally delete GPER shows that cardiomyocyte GPER is important for cardiac structure and function in both sexes (18). Interestingly, while GPER is expressed in the vasculature of both sexes (19, 20), the protective effects of GPER seem to be reversed in aging male mice, where global GPER deletion is protective against cardiac and vascular dysfunction $(21,22)$. Many of the cardiovascular effects of GPER are associated with changes in reactive oxygen species, suggesting an antioxidant role for this estrogen receptor.

Reactive oxygen species (ROS) are free radical and nonradical oxygen species including superoxide $\left(\mathrm{O}_{2}^{-}\right)$, hydrogen peroxide $\left(\mathrm{H}_{2} \mathrm{O}_{2}\right)$, peroxynitrite $\left(\mathrm{NO}_{3}^{-}\right)$, and hydroxyl radical (HO•). Excessive ROS overwhelms the cellular antioxidant system, causes oxidative stress, and promotes atherosclerosis, hypertension, stroke, and pathophysiological vascular remodeling (23-26). NADPH oxidase (Nox) proteins mediate electron transfer through catalytic subunits and significantly contribute to the production of ROS including superoxide and $\mathrm{H}_{2} \mathrm{O}_{2}$ (27). The Nox family of enzymes consists of Nox1 to Nox 5 and dual oxidases (Duox) Duox1 and Duox 2 which play diverse roles in the cardiovascular system (28). Many of the deleterious effects of Ang II are attributed to the generation of ROS via the recruitment of Nox proteins, as well as accessory proteins, to form a complex at the membrane (29). More specifically, Ang II upregulates the expression of Nox4 in vascular smooth muscle cells (30), an effect that is reversed by increasing cAMP signaling (31). Increased Nox4 expression is also found in models of Ang II-dependent hypertension including the spontaneously hypertensive rat (31) and the mRen2 rodent model (30). Therefore, the regulation of Nox proteins may be critical in mediating the adverse effects of Ang II.

Since GPER decreases NADPH-generated superoxide in carotid and intracranial arteries (32), Nox proteins may play a role in its vascular antioxidant effects. In vitro application of a GPER antagonist upregulates Nox1 but not Nox2 or Nox4, while global GPER deletion is associated with lower expression of Nox1 in the aorta and heart of aging male mice (21). In contrast to the lack of changes in Nox4 in male mice, ovariectomy-induced upregulation of cardiac Nox4 is prevented by chronic administration of the GPER agonist G-1 (11), while cardiomyocyte-specific GPER deletion in female mice induces a 4-fold increase in Nox4 mRNA (33). Therefore, the objective of this study was to investigate sex differences in the impact of GPER on Ang II-induced hypertension, oxidative stress, and Nox expression. We hypothesized that female responses to Ang II would be lower than males, while global GPER deletion would attenuate the protective effects of female sex. Moreover, we hypothesized that the antioxidant effects of GPER would be associated with changes in Nox.

\section{MATERIALS AND METHODS}

\section{Animals}

All procedures were carried out in accordance with the $\mathrm{NIH}$ Guide for the Care and Use of Laboratory Animals and approved by the Tulane University Institutional Animal Care and Use Committee. The GPER knockout strain used in this study was derived from the original model created by homologous recombination $(17,34)$. Male and female wildtype and global GPER knockout mice were bred and maintained in the institutional vivarium. The presence or absence of GPER was verified using both genotyping and ddPCR as previously described (35). Mice had free access to food and water in a temperature-controlled room $\left(65-75^{\circ} \mathrm{F}\right)$ with a $12 \mathrm{~h}$ light to dark cycle. Mice were anesthetized for implantation of radiotelemetry probes in the carotid artery. After recovery and recording of baseline cardiovascular parameters, osmotic minipumps (Alzet Model 1002) containing Ang II (Bachem) were implanted to infuse at a rate of $700 \mathrm{ng} / \mathrm{kg} / \mathrm{min}$ for 2 weeks, a protocol previously shown to induce sex differences in Ang II-induced hypertension $(36,37)$. Mice were euthanized at 18-25 weeks of age using isoflurane, and mesenteric arteries were harvested for measurement of vascular reactivity as described below. Aortas were stripped of fat, washed in PBS, and stored in $-80^{\circ} \mathrm{C}$ until use. Male and female Sprague Dawley rats were obtained at 3-6 months of age from Charles River for use in cell culture studies.

\section{Vascular Reactivity}

Mesenteric arteries were cleaned of surrounding connective tissue, cut into $2-\mathrm{mm}$ ring segments, and mounted on two wires connected to an isometric force transducer (DMT 620 M, Ann Arbor, MI). Segments were bathed in Krebs buffer $(118 \mathrm{mM}$ $\mathrm{NaCl}, 25 \mathrm{mM} \mathrm{NaHCO} 3,4.8 \mathrm{mM} \mathrm{KCl}, 2.5 \mathrm{mM} \mathrm{CaCl} 2,1.2 \mathrm{mM}$ $\mathrm{MgSO}_{4}, 1.2 \mathrm{mM} \mathrm{KH}_{2} \mathrm{PO}_{4}$, and $11 \mathrm{mM}$ glucose; $\mathrm{pH} 7.4$ ) and mixed with $95 \% \mathrm{O}_{2}$ and $5 \% \mathrm{CO}_{2}$ at $37^{\circ} \mathrm{C}$. Normalization and assessment of baseline vascular dynamics were done as previously described (35). Vascular contractility was assessed in response to increasing concentrations of angiotensin II (Ang II; $10^{-10}$ to $10^{-6} \mathrm{M}$ ) and prostaglandin $\mathrm{F} 2 \alpha\left(\mathrm{PGF} 2 \alpha ; 10^{-8}\right.$ to $10^{-4}$ $\mathrm{M})$. Vascular relaxation to increasing concentrations of sodium nitroprusside (SNP) or acetylcholine $\left(10^{-10}\right.$ to $\left.10^{-5} \mathrm{M}\right)$ were assessed in vessels pre-constricted with $10^{-5} \mathrm{M}$ phenylephrine.

\section{Cell Culture}

The embryonic rat aortic smooth muscle (A7r5) cell line was obtained from ATCC (Cat\# CRL-1444, RRID:CVCL_0137). Since these cells are of embryonic origin as assumed to be a mixture of both male and female cells, additional experiments utilized primary aortic smooth muscle cells isolated from the thoracic aorta of male and female Sprague Dawley rats (12-14 weeks of age). Cells were cultured for up to ten passages in Media 199 containing $10 \% \mathrm{FBS}, 1 \%$ penicillin-streptomycin and $1 \% \mathrm{~L}$ glutamine in $95 \%$ air, $5 \% \mathrm{CO}_{2}$ in $37^{\circ} \mathrm{C}$ incubator. Cells were grown to near confluence $(80 \%-90 \%)$ then switched to phenol red-free Media 199 containing 0.5\% charcoal-stripped serum, 1\% penicillin-streptomycin, and 1\% L-glutamine. Cells were treated in the presence or absence of GPER agonist G-1 (100 nM), GPER 
antagonist G36 (10 $\mu \mathrm{M})$ (38), adenylyl cyclase inhibitor SQ22536 $(5 \mu \mathrm{M})$, and phosphodiesterase- 4 inhibitor rolipram $(5 \mu \mathrm{M})$ for $24 \mathrm{~h}$ before being exposed to Ang II (100 nM) for $4 \mathrm{~h}$.

\section{Immunoblotting}

After treatment, cells were washed and collected in ice cold phosphate-buffered solution then lysed in RIPA buffer containing protease and phosphatase inhibitors. Protein was estimated using the Pierce ${ }^{\mathrm{TM}}$ BCA Protein Assay Kit, and $50 \mu \mathrm{g}$ of protein was resolved in a $10 \%$ Sodium dodecyl sulfate gel by electrophoresis before being transferred to a $0.45 \mu \mathrm{m}$ nitrocellulose membrane for $2 \mathrm{~h}$. Membranes were blocked in 5\% non-fat milk for $2 \mathrm{~h}$ and incubated overnight with anti-Nox4 (1:1,000; Abcam ab13330316), an antibody whose protein specificity was validated in other studies (39) as well as in our hands using siRNA (Figure 6D). Blots were reprobed with anti-GAPDH (GeneTex gtx627408) or anti- $\beta$ actin (Cell Signaling Technology 3700) as a loading control. Secondary antibodies against rabbit and mouse were used at a 1:1,000 dilution. Image Studio Lite Version 5.2 was used to analyze band intensity.

\section{Histology}

Aortas and hearts were fixed overnight in 10\% PBS buffered formalin and followed by storage in $70 \%$ ethanol. Paraffinembedded sections were stained with hematoxylin and eosin, and aortic wall thickness was measured by taking measurements along the aortic wall circumference perpendicular to the lumen at 10 points per sample. To assess for cardiac hypertrophy, the entire cross-section of the heart was imaged at $4 \times$ magnification with the Cytation 5 imaging reader (BioTek, Winooski, VT). Wall and lumen areas were measured to calculate the LV/lumen ratio.

\section{RNA Extraction and Reverse Transcription-Quantitative PCR}

Cells or tissues were subjected to RNA extraction using the Qiagen RNeasy mini kit (cat\# 74106). The amount of RNA was estimated using a NanoDrop 3300 Fluorospectrometer
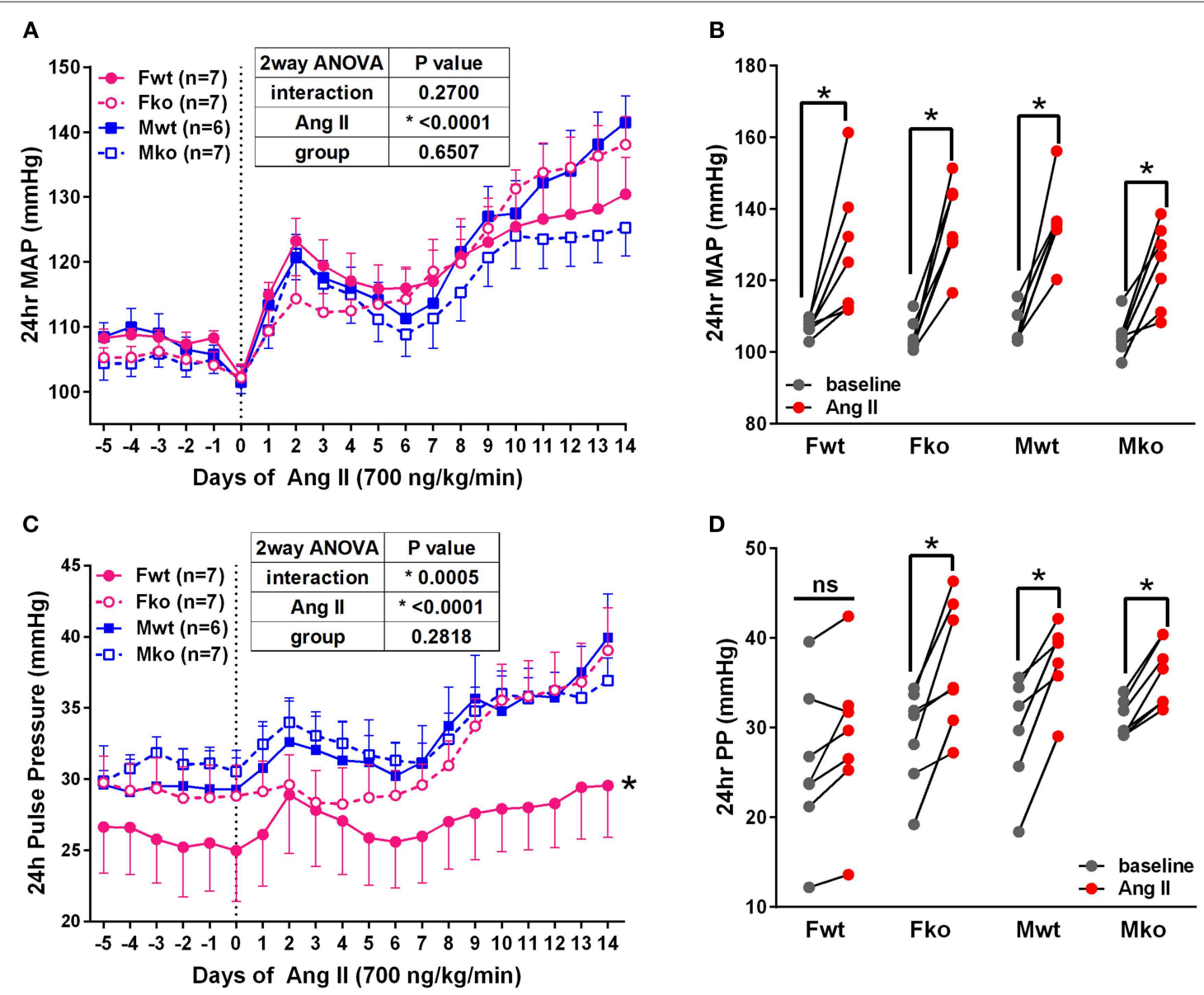

FIGURE 1 | GPER deletion increases pulse pressure in hypertensive female mice. (A) Radiotelemetry recordings show that MAP is not different at baseline or during 2-week Ang II infusion. (B) Grouped MAP pre and post Ang II shows a significant increase in all groups. 2-way repeated measures ANOVA, $p<0.0001$ for Ang II, Sidak, ${ }^{\star} p<0.005$ for all groups. (C) Pulse pressure was significantly lower in Fwt mice. Tukey's test for main column effect, ${ }^{\star} p<0.001$ vs. all other groups. (D) Grouped pulse pressure data pre and post Ang II shows a significant increase in all groups except Fwt. 2-way repeated measures ANOVA, $p<0.0001$ for Ang II, Sidak, ${ }^{\star} p<0.005$ vs. baseline. 
(RRID:SCR_015804). For real-time polymerase chain reaction, a total of up to $500 \mathrm{ng}$ RNA was used for PCR reaction. Specific rat primers for NOX4 (assay ID:qRnoCID0003969), NOX1 (assay ID:qRnoCID0004920), and GAPDH (assay ID:qRnoCID0057018) were obtained from Bio-Rad. For realtime PCR, $\mathrm{iTaq}^{\mathrm{TM}}$ Universal One-Step RT-qPCR Kit (cat\# 172-5151) was used. The reaction mixture was set for $10 \mathrm{~min}$ at $50^{\circ} \mathrm{C}$ for cDNA synthesis, $5 \mathrm{~min}$ at $95^{\circ} \mathrm{C}$ for reverse transcription inactivation, and $10 \mathrm{~s}$ at $95^{\circ} \mathrm{C}$ for PCR cycling. Detection was done for 30 cycles followed by $30 \mathrm{~s}$ in $60^{\circ} \mathrm{C}$ and a melt curve analysis for $1 \mathrm{~min}$ at $95^{\circ} \mathrm{C}$. The Bio- $\operatorname{Rad}^{\circledR} \mathrm{CFX} 96^{\mathrm{TM}}$ real-time PCR system was used to perform the assay in triplicate. To calculate the fold changes in mRNA expression, we normalized cycle threshold $[\mathrm{C}(\mathrm{t})]$ value of target genes to reference gene GAPDH using the $2^{-\Delta \Delta C t}$ method.

\section{Nox4 siRNA Transfection}

Small interference RNA duplexes targeting Nox4 (rat) were obtained from Origene (cat\# SR506919). Cells seeded in $35 \mathrm{~mm}$ dishes were grown to $60 \%$ confluence, and $20 \mu \mathrm{l}$ of transfection reagent Lipofectamine ${ }^{\circledR}$ Plus $^{\text {TM }}$ was added to $180 \mu \mathrm{l}$ Opti-MEM ${ }^{\mathrm{TM}}$ media for a final volume of 200 $\mu$ l. One hundred nanomolar of siRNA was then added and mixed in a $1 \mathrm{ml}$ tube and left to stand for $20 \mathrm{~min}$ at room temperature. The reaction mixture was added to each well to a final volume of $4 \mathrm{ml}$ Opti-MEM ${ }^{\mathrm{TM}}$ media. Cells were grown for an additional $30 \mathrm{~h}$ after transfection before experiments were performed.

\section{NADP/NADPH-Glo ${ }^{\mathrm{TM}}$ Assay}

Cells treated in 24-well plates were washed with $37^{\circ} \mathrm{C}$ PBS and left to equilibrate at room temperature. NADP/NADPH$\mathrm{Glo}^{\mathrm{TM}}$ detection reagent (cat\#G9081, Promega) was added to each well and placed on a shaker for $1 \mathrm{~h}$ at room temperature. Luminescence was recorded using a Synergy ${ }^{\mathrm{TM}}$ HTX MultiMode Microplate Reader and normalized to protein in each well and expressed as relative luminescence units (RLU) per mg protein.

\section{Catalase Colorimetric Assay Activity}

Cells cultured in 12-well plates were washed twice in ice cold PBS and scraped followed by centrifugation at $250 \times \mathrm{g}$ for $10 \mathrm{~min}$.
The cell pellet was collected and re-suspended in $1 \mathrm{X}$ assay buffer and sonicated. Finally the lysate was centrifuged at $10,000 \times \mathrm{g}$ for $15 \mathrm{~min}$ and a portion of the supernatant was subjected to catalase colorimetric activity kit (ThermoFisher Scientific cat\# EIACATC). Briefly, the generated standard curve and protein absorbance was read at $560 \mathrm{~nm}$ using Synergy ${ }^{\mathrm{TM}}$ HTX MultiMode Microplate Reader and normalized to protein in each wellestimated by BCA method. Final results are expressed as units (U) per mg protein.

\section{Electron Spin Resonance Spectroscopy (ESR)}

ESR was used to measure ROS in cells and isolated aortic tissues using the spin probe 1-hydroxy-3-methoxycarbonyl-2, 2, 5, 5tetramethyl-pyrrolidine $(\mathrm{CMH})$ as previously described (40). Diethyldithiocarbamate (DETC; $2.5 \mu \mathrm{mol} / \mathrm{l}$ ) and desferoxamine (DF, $25 \mu \mathrm{mol} / \mathrm{l}$ ) were dissolved under nitrogen gas bubbling in ice-cold modified Krebs-Hepes (KH) buffer. Media containing drug treatments was removed before analysis, to avoid potential interference with the $\mathrm{CMH}$ signal. Cells or tissues were washed with calcium- and magnesium-free Dulbecco's phosphatebuffered saline (DPBS) and incubated with freshly prepared $\mathrm{CMH}(200 \mu \mathrm{mol} / \mathrm{L})$ solution in $\mathrm{KH}$ buffer containing DETC and $\mathrm{DF}$ at $37^{\circ} \mathrm{C}$ for $60 \mathrm{~min}$. Samples with buffer were transferred to $1 \mathrm{ml}$ syringes, snap frozen in liquid nitrogen, and stored at $-80^{\circ} \mathrm{C}$ until analysis. Samples were transferred to a finger Dewar vessel (Noxygen Science Transfer and Diagnostics, Germany) and analyzed using an EMX ESR Benchtop spectrometer (Bruker, Germany) with the following ESR settings: center field, $1.99 \mathrm{~g}$; microwave power, $20 \mathrm{~mW}$; modulation amplitude, $2 \mathrm{G}$; sweep time, $10 \mathrm{~s}$; number of scans, 10; field sweep, $60 \mathrm{G}$. The amplitudes of the spectra were normalized using protein concentration and expressed as arbitrary units per mg protein.

\section{Statistics}

Statistical analysis was performed using GraphPad Prism 6.07 software (GraphPad Software). Outliers were identified using the ROUT method. For one factor analysis, the Shapiro-Wilk test was used to determine normality. Unpaired $t$-test was used to determine the difference between two groups. One-way ANOVA was used to determine differences between three or

TABLE 1 | Cardiovascular parameters.

\begin{tabular}{|c|c|c|c|c|c|c|c|}
\hline & \multirow[t]{2}{*}{ Fwt } & \multirow[t]{2}{*}{ Fko } & \multirow[t]{2}{*}{ Mwt } & \multirow[t]{2}{*}{ Mko } & \multicolumn{3}{|c|}{ 2-way ANOVA } \\
\hline & & & & & Interaction & Ang II & Group \\
\hline Baseline SBP & $120 \pm 2$ & $118 \pm 2$ & $121 \pm 2$ & $119 \pm 2$ & 0.3337 & ${ }^{\star}<0.0001$ & 0.2670 \\
\hline Ang II SBP & $142 \pm 7$ & $151 \pm 6$ & $156 \pm 4$ & $142 \pm 5$ & & & \\
\hline Baseline DBP & $94 \pm 2$ & $89 \pm 1$ & $92 \pm 2$ & $88 \pm 2$ & 0.4870 & ${ }^{\star}<0.0001$ & 0.3790 \\
\hline Ang II DBP & $114 \pm 7$ & $115 \pm 4$ & $118 \pm 6$ & $106 \pm 4$ & & & \\
\hline Baseline HR & $596 \pm 16$ & $595 \pm 10$ & $550 \pm 8$ & $571 \pm 12$ & 0.4966 & ${ }^{*} 0.0024$ & ${ }^{*} 0.0013$ (Sidak, Mwt, $\left.P=0.04\right)$ \\
\hline Ang $\| \mathrm{HR}$ & $588 \pm 13$ & $580 \pm 8$ & $517 \pm 11$ & $551 \pm 9$ & & & \\
\hline
\end{tabular}

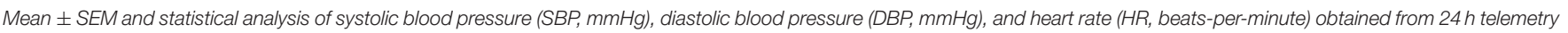
recordings at baseline and after 2-week infusion of Ang II. 
more groups, and if significant Tukey's multiple comparison test was performed. For data that was not normally distributed, Kruskal-Wallis with Dunn's multiple comparison was used. Twoway repeated measures ANOVA was used to analyze timeline and sex differences data, with no assumptions of sphericity, Geisser-Greenhouse corrections, and Tukey's test. For pre/post data, sphericity was assumed and multiple comparisons were made with Sidak's test. Comparisons where $P<0.05$ were considered significant. All experiments were repeated at least once. Information on statistical tests used are also provided in graph legends.

\section{RESULTS}

\section{GPER Deletion in Females Impacts Pulse Pressure but Not Mean Arterial Pressure}

To determine the impact of genetic GPER deletion on cardiovascular parameters at baseline and during hypertension, male and female ( $\mathrm{M}$ and $\mathrm{F}$ ) wildtype and GPER knockout (wt and ko) mice were implanted with telemetry probes and exposed to Ang II for 2 weeks. As shown in Figure 1, no significant differences in MAP were found at baseline or in response to Ang II (Figure 1A). There was a trend for lower MAP in Mko

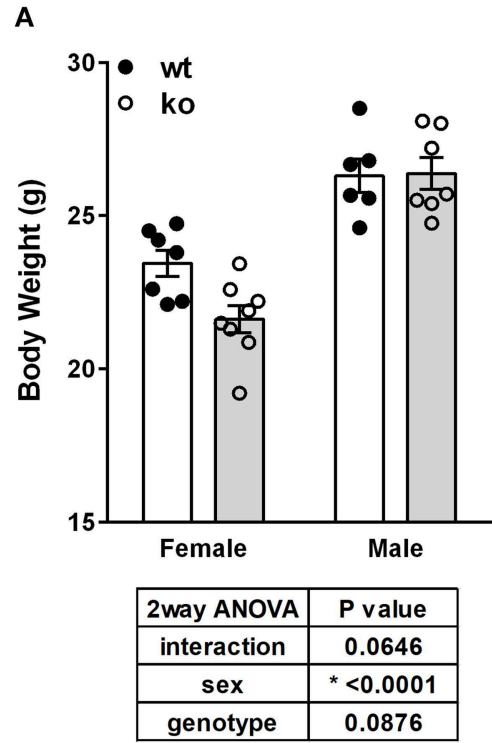

D

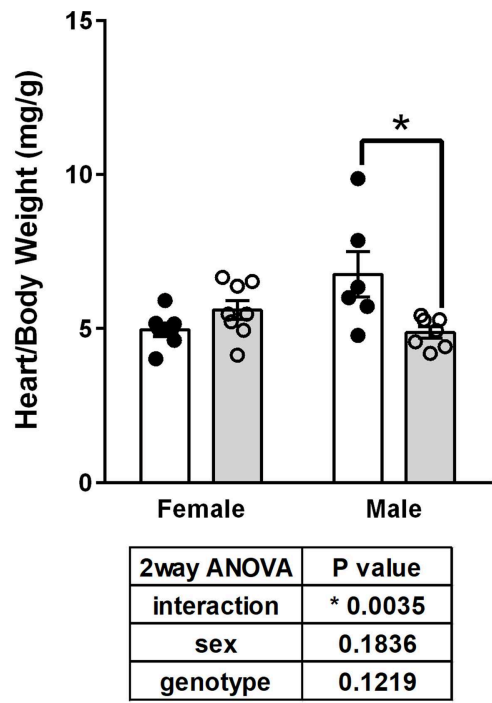

B

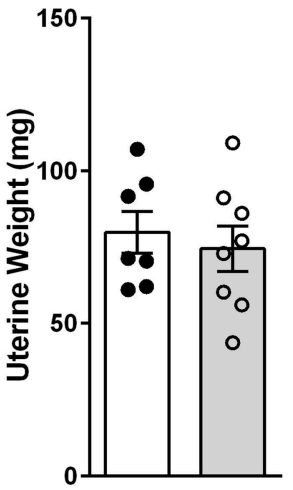

Female

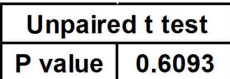

C

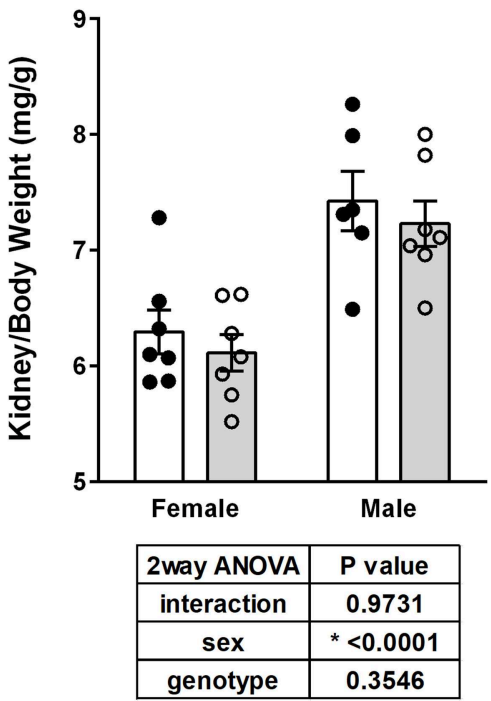

$\mathbf{F}$

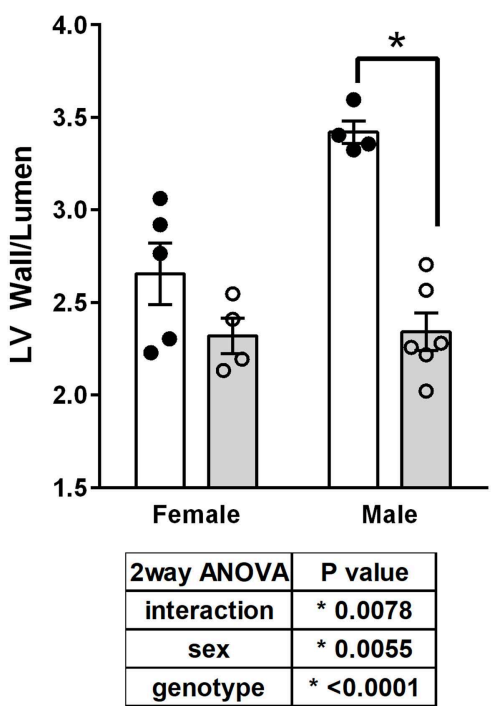

FIGURE 2 | GPER deletion impacts tissue weights and left ventricle wall thickness. (A) Body weight, (B) Uterine weight, (C) Kidney-to-body weight ratio, and (D) Heart-to-body weight ratio, all with respective statistical test results and Sidak's test if applicable. (E) A significant and positive correlation was found between final pulse pressure and heart-to-body weight ratio. (F) Left ventricular (LV) wall thickness-to-lumen ratio was higher in Ang II-infused Mwt versus Mko mice. 
mice that did not reach statistical significance. Ang II induced a significant increase in blood pressure in all groups (Figure 1B). Analysis of systolic and diastolic pressures did not reveal any impact of genotype (Table 1). The ability of Ang II-induced hypertension to decrease heart rate was significant only in the Mwt group. Interestingly, Fwt mice had significantly lower pulse pressures than all other groups, while Fko pulse pressure was similar to Mwt and Mko mice (Figure 1C). In addition, pulse pressure was significantly increased by Ang II hypertension in all groups except Fwt mice (Figure 1D).

\section{Impact of GPER Deletion on Wall Thickness, Nox Expression, and Vascular Reactivity}

In Ang II-infused mice, body weight and kidney weight ratios were significantly higher in males but not impacted by genotype (Figures 2A,C). Uterine weights were not impacted by genotype (Figure 2B). A sex difference in cardiac weight ratios was observed in wt but not GPER ko mice (Figure 2D). Left ventricular wall-to-lumen ratio was impacted by GPER ko in male but not female mice (Figure 2F). A significant and positive correlation was found between final pulse pressure and heartto-body weight ratio (Figure 2E). Assessment of aortic cross sections indicated a significant interaction between genotype and sex with increased wall thickness in Fko vs. Fwt with no impact in male mice (Figure 3A). To investigate the impact of Ang II on aortic Nox4 and Nox1, a separate cohort of mice was infused with Ang II for 2 weeks at the same dose or used as controls. Nox4 mRNA was significantly increased by Ang II treatment in all groups except Fwt mice (Figure 3B), while Nox1 mRNA was increased in female ko mice only (Figure 3C). Mesenteric arteries from female GPER ko and wt mice infused with Ang II were also assessed for vascular reactivity. Vessel contraction to increasing concentrations of PGF $2 \alpha$ or Ang II was not significantly different between Fko and Fwt mice (Figures 3D,E). Similarly, relaxation to acetylcholine or SNP in pre-constricted vessels was also comparable between GPER ko and wt females (Figures 3F,G).

\section{GPER Activation Prevented Ang II-Induced Increases in ROS and NADP/NADPH Ratio}

To determine whether GPER impacts vascular Nox4 and oxidative stress, we designed in vitro experiments using A7r5 aortic smooth muscle cells (ASMC). Ang II-induced ROS was prevented by the GPER agonist G-1 (Figure 4A). Similarly, G1 blocked Ang II-induced increases in NADP/NADPH ratio but did not alter levels when given alone (Figure 4B). Since A7r5 cells are embryonic and most likely contain a mixture of male and female cells, we assessed sex differences in the impact of GPER on oxidative stress. Surprisingly, primary isolated female ASMC had higher levels of ROS when assessed in estrogen-free conditions, but G-1 similarly attenuated the impact of Ang II in cells from both sexes (Figure 4C). To confirm involvement of

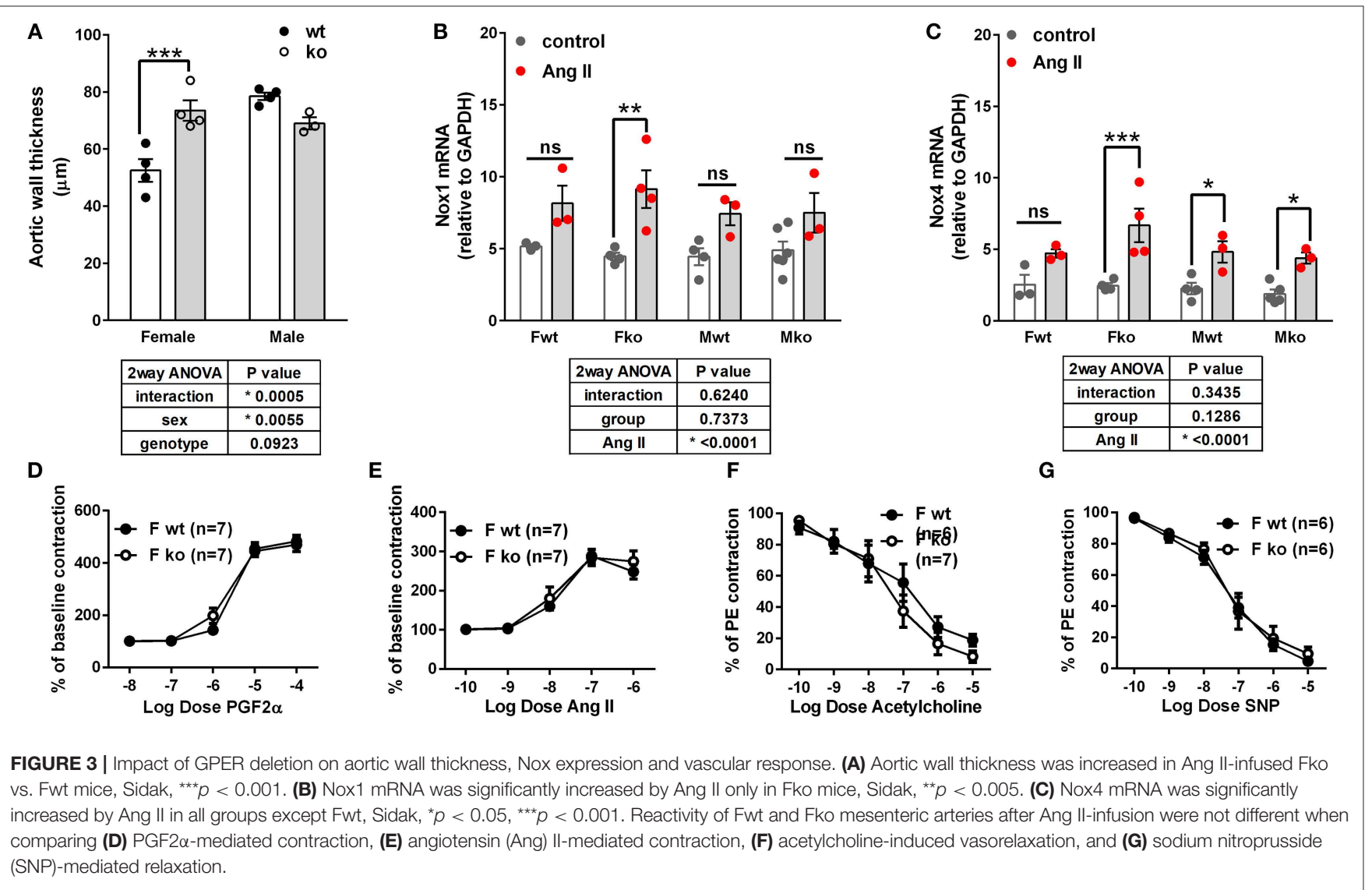


A

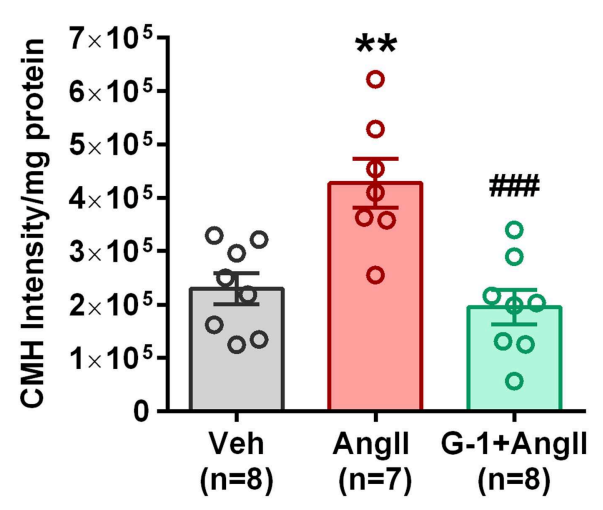

B

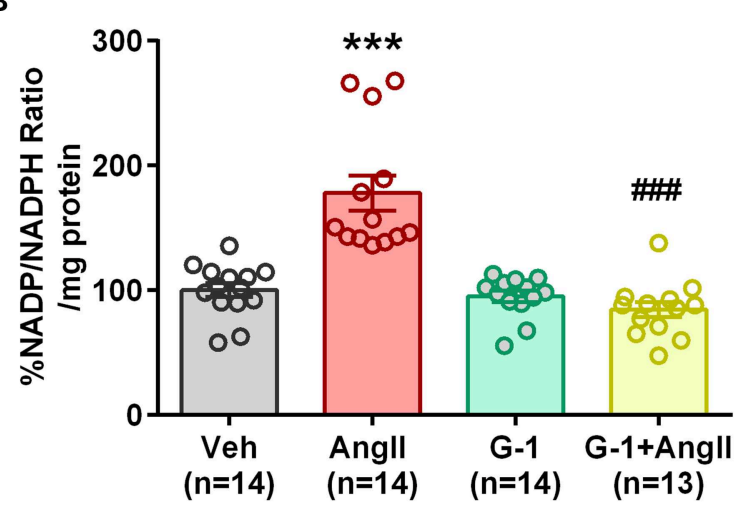

C

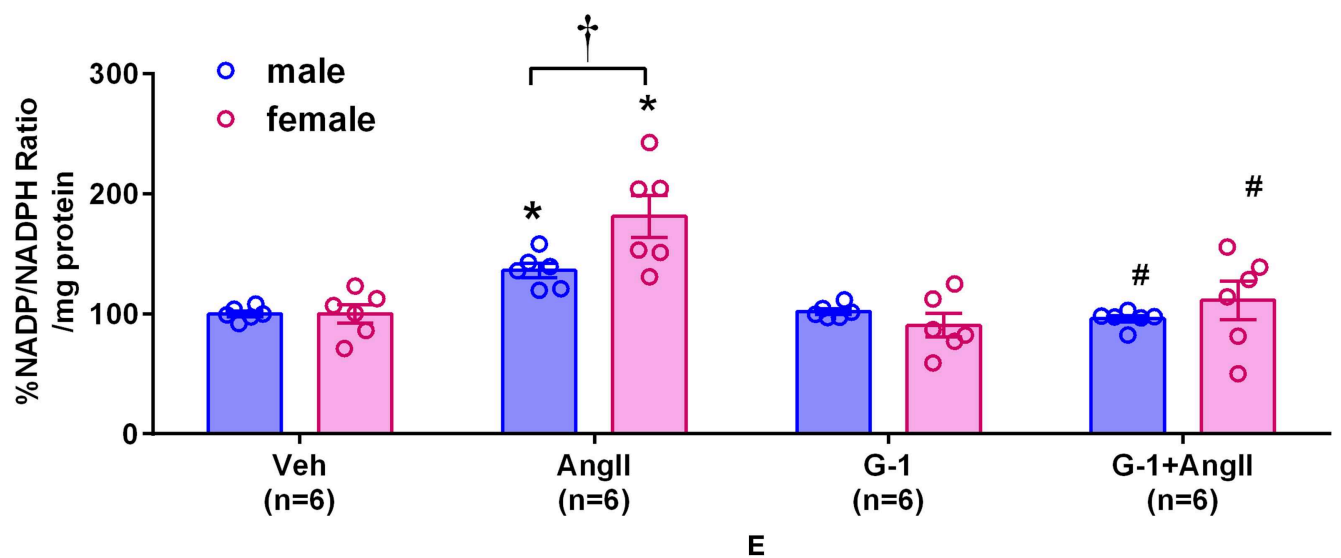

D

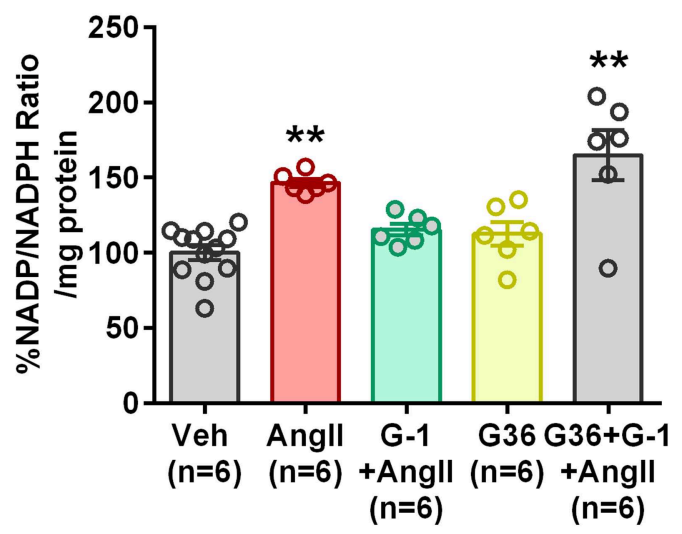

E

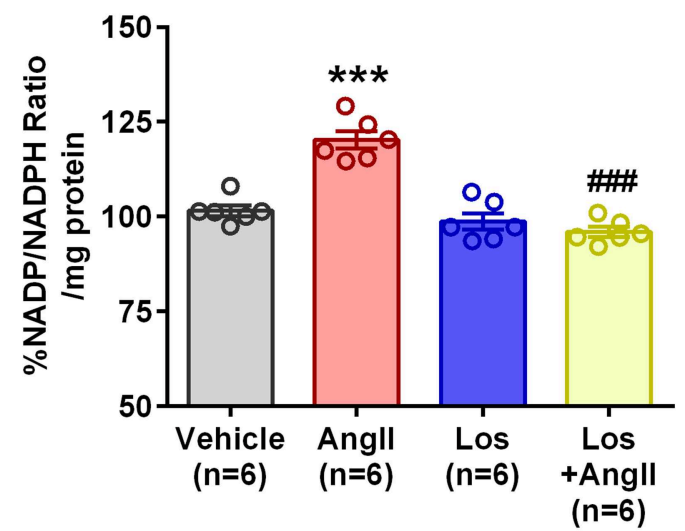

FIGURE 4 | GPER activation prevented Ang Il-induced increases in ROS and NADP/NADPH ratio. (A) Stimulation of A7r5 cells with $100 \mathrm{nM}$ Ang II for $4 \mathrm{~h}$ significantly increased ROS, which was prevented by pretreatment with the GPER agonist G-1 for $24 \mathrm{~h}$. 1 -way ANOVA, $p=0.0004$, Tukey ${ }^{* *} p<0.01$ vs. vehicle (Veh); $\# \# \# p<$ 0.0001 vs. Ang II. (B) Ang II-induced increases in the NADP/NADPH ratio were also mitigated by G-1. Kruskai-Wallis test, $p<0.0001$, Dunn, ${ }^{\star \star \star} p<0.001$ vs. Veh; $\# \# \# p<0.001$ vs. Ang II. (C) Ang II also increased NADP/NADPH ratio in primary male and female Sprague Dawley rat aortic smooth muscle cells, which was reversed by G-1. 2-way ANOVA with Geisser-Greenhouse correction, ${ }^{*} p<0.0323$ for interaction, Tukey, ${ }^{*} p<0.05$ vs. Veh; ${ }^{*} p<0.05$ vs. Ang II; ${ }^{\dagger} p<0.01$ sex effect. (D) The GPER antagonist G36 blocked the ability of G-1 to inhibit Ang Il effects on NADP/NADPH ratio. 1-way ANOVA, $p<0.0001$, Tukey, ${ }^{* *} p<0.01$ vs. Veh. (E) The increase in NADP/NADPH ratio induced by Ang II was completely prevented by losartan (Los). 1-way ANOVA, $p<0.0001$, Tukey, ${ }^{* \star *} p<0.001$ vs. vehicle; $\# \# \# p<0.001$ vs. Ang II.

GPER, cells were treated with Ang II and G-1 in the presence or absence of the GPER antagonist G36. The data consistently showed that Ang II increased while G-1 reversed NADP/NADPH ratio, but blocking GPER with G36 rendered G-1 ineffective in reversing the effect of Ang II (Figure 4D). To confirm the role of the Ang II type 1 receptor (AT1R) in mediating the effects of Ang II, we examined NADP/NADPH ratio in the presence or absence of the AT1R antagonist losartan (Figure 4E). 

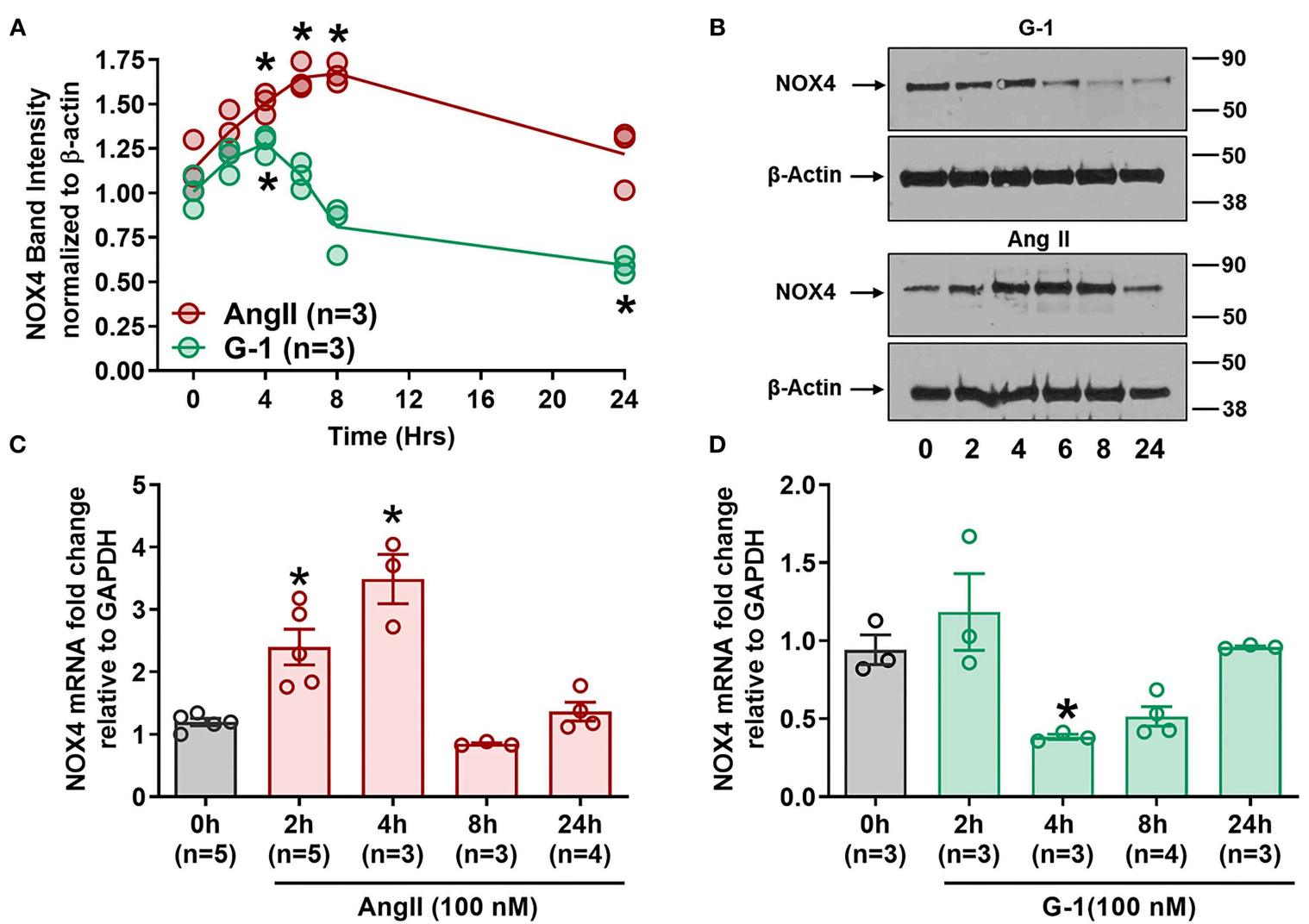

FIGURE 5 | GPER and Ang II regulate Nox4 protein and mRNA. (A) Ang II increased Nox4 protein at 4, 6, and 8h while G-1 downregulated Nox4 protein at $24 \mathrm{~h}$. 2-way ANOVA, $p<0.001$ for interaction, Dunnett, ${ }^{*} p<0.05$ vs. 0 h. (B) Representative blots for (A). (C) Ang II and (D) G-1 also impacted Nox4 mRNA. 1-way ANOVA, $p<0.01$, Dunnett, ${ }^{*} p<0.05$ vs. 0 h.

Losartan completely blocked the Ang II-induced increase in NADP/NADPH ratio.

\section{GPER and Ang II Regulate Nox4 Protein and mRNA}

Since GPER attenuated Ang II-induced ROS and NADP/NADPH ratio, we next determined its impact on Nox4. Ang II upregulated Nox4 protein in A7r5 cells at 4, 6, and $8 \mathrm{~h}$ compared with baseline, while G-1 significantly decreased Nox4 protein expression at $24 \mathrm{~h}$ (Figures 5A,B). RT-qPCR showed that Nox4 mRNA levels were significantly increased by Ang II at 2 and $4 \mathrm{~h}$ (Figure 5C) but were decreased by G-1 at $4 \mathrm{~h}$ when compared with controls (Figure 5D). Nox4 mRNA was restored to control levels after $24 \mathrm{~h}$ of either G-1 or Ang II. These experiments indicated that Ang II and GPER regulate Nox4 in opposite directions at the transcriptional level.

\section{GPER Activation Prevents Ang II-Induced Upregulation of Nox4 Protein}

We next determined whether pretreatment with the GPER agonist prevented Ang II-induced increases in Nox4 mRNA and protein. G-1 pretreatment for $24 \mathrm{~h}$ did not alter Nox 4 expression alone but prevented the upregulation induced by
Ang II (Figures 6A,B). We used catalase activity to indirectly determine the amount of $\mathrm{H}_{2} \mathrm{O}_{2}$ produced when we blocked or activated GPER. Ang II significantly downregulated catalase activity, but this effect was ameliorated in the presence of G-1 (Figure 6C). The antagonist G36 eliminated the ability of G-1 to inhibit the effects of Ang II on Nox4 protein (Figures 6D,E) as well as catalase activity (Figure 6F).

\section{siRNA Knockdown of Nox4 Reduced Ang II Effects}

We utilized small interference (si) RNA for Nox4 to determine the role of this protein in Ang II-mediated oxidative stress, and validation of protein downregulation is shown in Figure 7D. Nox4 siRNA completely abrogated Ang II-induced ROS production (Figure 7A) and NADP/NADPH ratio (Figure $7 \mathbf{B}$ ) compared with scrambled siRNA controls. Nox4 knockdown also prevented Ang II-induced Nox4 protein upregulation by $80 \%$ (Figures 7C,E), an effect similar to that seen with G-1 treatment.

\section{Impact of CAMP Signaling}

We next investigated the role of GPER-mediated cAMP production in the protective effects of G-1 on NADPH oxidase activity and Nox4 protein expression. A7r5 cells were treated with Ang II in the presence or absence of the GPER agonist 
A

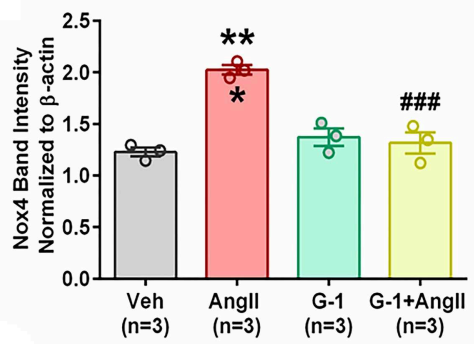

D

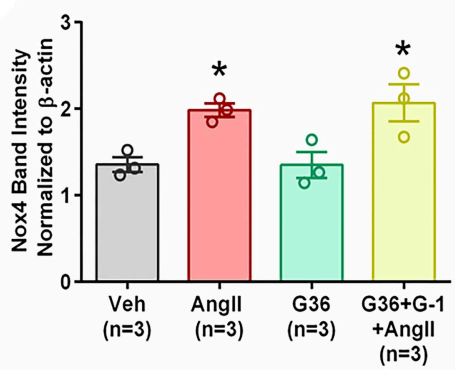

B

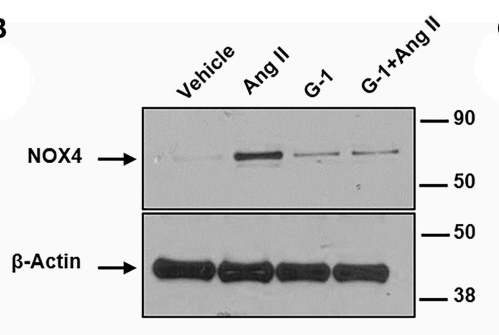

E

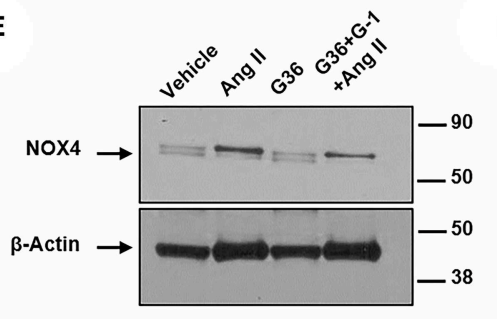

C

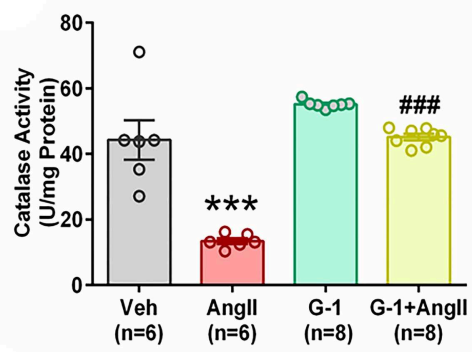

F

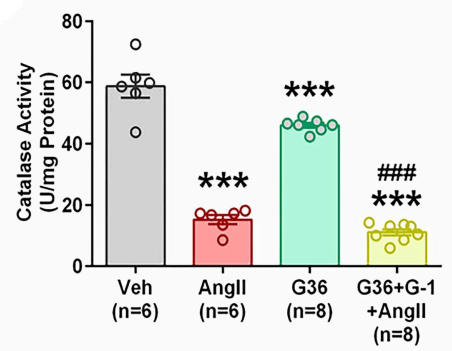

FIGURE 6 | GPER activation prevents Ang II-induced upregulation of Nox4 protein. (A) Ang II-induced Nox4 protein is reversed by G-1. 1-way ANOVA, $p=0.0002$, Tukey, ${ }^{* \star *} p<0.001$ vs. vehicle (Veh); $\# \# \# p<0.001$ vs. Ang II. (B) Representative blot for (A). (C) Ang II-induced decreased catalase activity while G-1 prevented the decrease. 1-way ANOVA, $p<0.0001$, Tukey, ${ }^{* \star *} p<0.001$ vs. vehicle; $\# \# \# p<0.001$ vs. Ang II. (D) The GPER antagonist G36 blocked the ability of G-1 to inhibit Ang II effects on Nox4 protein. 1-way ANOVA, $p=0.0106$, Tukey, ${ }^{*} p<0.05$ vs. Veh. (E) Representative immunoblot for (C). (F) G36 blocked the effect of G-1 on Ang II-induced decreased catalase activity. 1-way ANOVA, $p<0.0001$, Tukey, ${ }^{\star \star \star} p<0.001$ vs. Veh; $\# \# \# p<0.001$ vs. G36.

G-1, the adenylyl cyclase inhibitor SQ22536 (SQ), or the phosphodiesterase (PDE) 4 inhibitor rolipram, which increases intracellular cAMP levels by preventing its breakdown. G-1 again prevented Ang II-induced increases in NADP/NADPH ratio, but SQ blocked this effect (Figure 8A). Similarly, when adenylyl cyclase was inhibited, G-1 was unable to prevent the effect of Ang II on Nox4 protein (Figures 8B,C) and catalase activity (Figure 8D). Rolipram mimicked the effects of GPER activation by blocking Ang II-induced NADP/NADPH activity (Figure 8E), Nox4 upregulation (Figures 8F,G), and decreased catalase activity (Figure $\mathbf{8 H}$ ).

\section{DISCUSSION}

The novel finding from the current study is that despite similar blood pressures, GPER deletion in female mice significantly increased pulse pressure and exacerbated the upregulation of aortic NADPH oxidases in response to Ang II. In parallel, in vitro activation of GPER attenuated oxidative stress via cAMPmediated regulation of Nox4. We demonstrated that Nox4 plays a major role in Ang II-induced ROS production in cultured VSMC. Furthermore, we showed that GPER opposed the effects of Ang II by downregulating Nox4 at the transcriptional level and restoring catalase activity. These findings have important implications since randomized clinical trials fail to significantly inhibit oxidative stress using currently available antioxidants such as vitamin E (41-43), while preclinical studies with Nox1 and 4 inhibitors $(44,45)$ are promising. Since oxidative stress is detrimental to cardiovascular tissues, GPER may provide a novel target for inhibition of vascular ROS.

In contrast to previous studies, we did not find a sex difference in Ang II-induced hypertension as found in other studies using the same or similar protocol $(36,37)$. A study using a higher dose of Ang II also failed to detect sex differences in telemetry blood pressure recordings (46). Since the mice used in this study were developed from a $129 / \mathrm{Sv}$ strain and backcrossed to the C57bl/6, some genetic aspects of the $129 / \mathrm{Sv}$ strain may have carried over $(34,47)$, since mice of this strain have two renin genes and higher blood pressures even after two generations of backcrossing with C57bl/6 mice $(48,49)$. Four GPER knockout mice strains have been created using slightly different methods (13), and in this study the model created by homologous recombination was utilized $(17,34)$. The results from these different models is varied, for example previous data from this same strain utilized in the current study shows increased body weight in both male and female knockout mice at 10 months of age (15). In contrast, data from a different GPER knockout strain shows lower body weight in Fko at 19 weeks of age, and also finds increased mean arterial pressure in female knockout mice at 9 months of age but not at 6 months, the latter of which is comparable to the ages of the mice in our study (17). We found no difference in body weight or blood pressure before or after Ang II infusion, suggesting that age and strain are important factors in observing these phenotypes.

Since sex did not influence Ang II hypertension and the hypothesis was that GPER deletion would remove sex differences, we were not surprised to find similar MAP in wt and ko mice. 
A

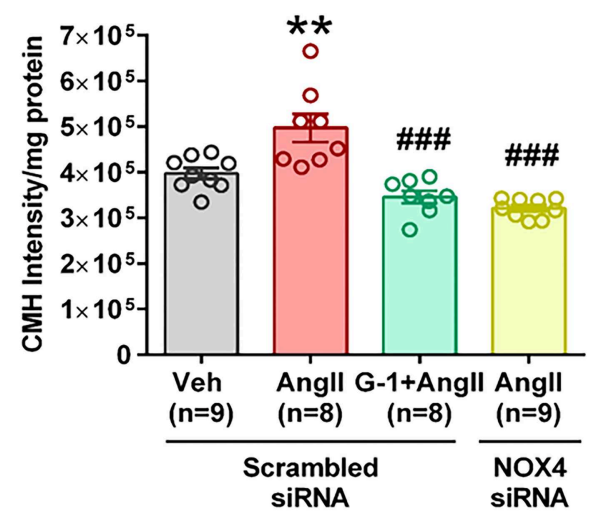

C

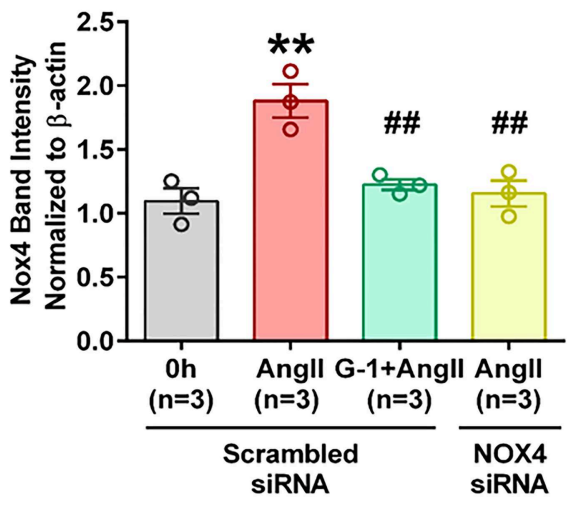

B

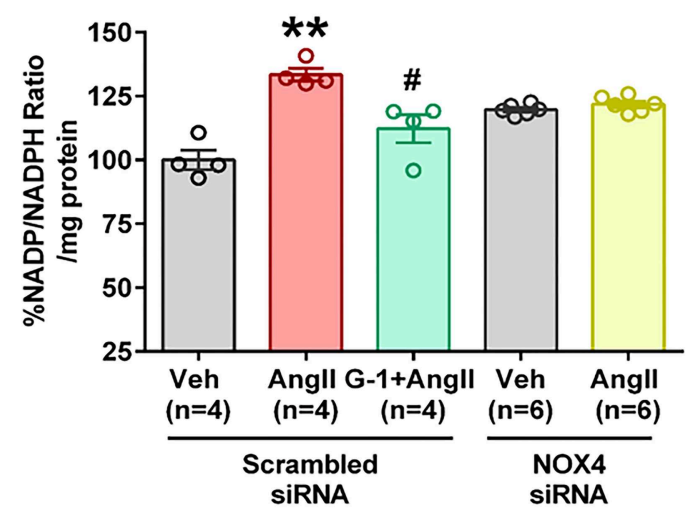

D

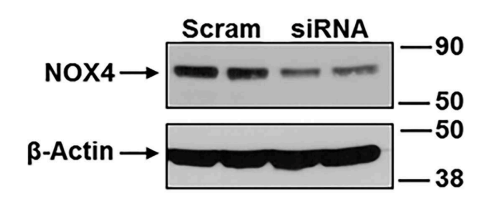

E

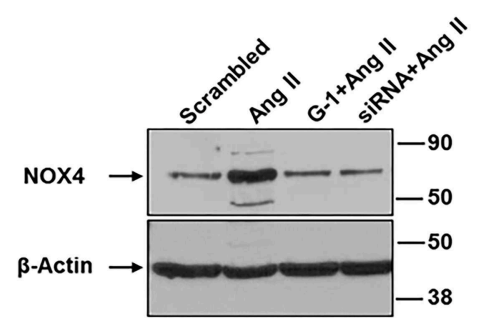

FIGURE 7 | siRNA knockdown of Nox4 reduced Ang II effects. (A) Nox4 siRNA significantly reduced Ang Il-induced ROS. 1-way ANOVA, $p<0.0001$, Holm-Sidak, ${ }^{* *} p<0.01$ vs. Veh; \#\#\# $p<0.0001$ vs. Ang II. (B) Nox4 siRNA significantly reduced Ang II-induced NADP/NADPH ratio. Kruskai-Wallis test, $p=0.0012$, Dunn ${ }^{* *} p$ $<0.01$ vs. Veh; $\# p<0.05$ vs. Ang II. (C) Ang II upregulated Nox4 protein in the presence of scrambled (Scr) siRNA but not with Nox4 siRNA. 1 -way ANOVA, $p=$ 0.0017 , Tukey, ${ }^{*} p<0.05$ vs. Veh; \#\# $p<0.01$ vs. Ang II. (D) Validation of Nox4 antibody and siRNA. (E) Representative blot for (C).

However, we found a significant impact of GPER deletion when analyzing pulse pressure, an indicator of arterial stiffening, which was increased in Fko mice to a level comparable to male wt and ko mice. These data support our previous study in salt-loaded mRen2 rats where despite similar levels of hypertension, aortic wall thickness was significantly reduced by chronic treatment with the GPER agonist G-1 (9). The increased stiffness observed may precede changes in pressure, considering that arterial stiffening is observed before increases in blood pressure in aging humans as well as a mouse model of high fat dietinduced hypertension (50-52). While arterial stiffening increases afterload, cardiac hypertrophy was not different in Fwt vs. Fko mice in the current study. However, the significant positive correlation with pulse pressure indicates that arterial stiffening is associated with increased cardiac remodeling, but longer Ang II infusion may be required to observe differences between groups. The current study indicates that in female mice, GPER provides protection from Ang II-induced vascular remodeling and pulse pressure increases, but not hypertension.

Using ESR spectroscopy, the best method for detecting and analyzing ROS in biological samples (40), we confirmed that GPER activation promotes antioxidant defenses in the vasculature. This result is consistent with studies showing that estrogen attenuates oxidative stress in VSMC (53) and endothelial cells (6). Previous work from our laboratory indicates that GPER attenuates vascular oxidative stress and remodeling (9), decreases cardiac ROS (11), and reduces renal oxidative damage in rats fed a high salt diet (10). In addition, deficiency of GPER in cardiomyocytes of female mice is associated with increased cardiac oxidative stress (33). Mechanisms for the antioxidant effect of GPER in other cell types include a reduction in mitochondrial permeability transition pore opening in cardiac cells (54), regulation of several antioxidant genes including glutathione peroxidase and thioredoxin-interacting protein in skeletal muscle (33), and reduced $\mathrm{H}_{2} \mathrm{O}_{2}$ peroxidation in the liver (6). Recent evidence also suggests that GPER induces superoxide dismutase during methotrexate-induced kidney damage (55). In the rat heart, ovariectomy increases Nox4 expression and oxidative stress and is reversed by administration of the GPER agonist G1 (11). Notably, deletion of GPER in cardiomyocytes increases Nox4 and oxidative stress in female mice (33), suggesting a detrimental role for this enzyme in the heart (56). 


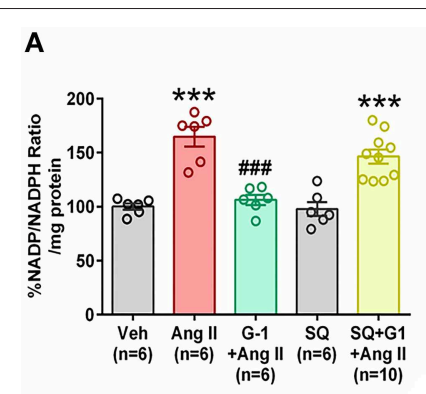

E

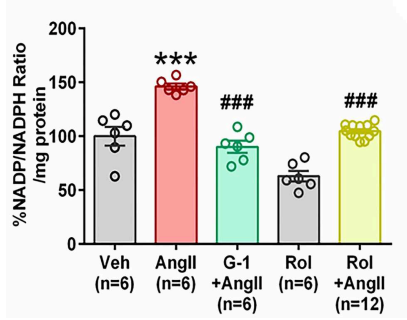

B

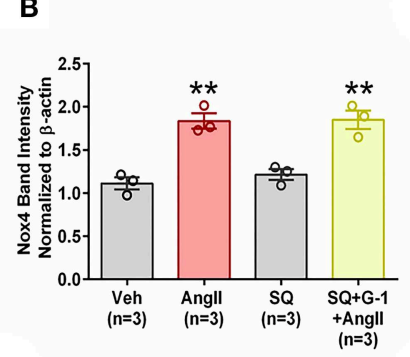

F

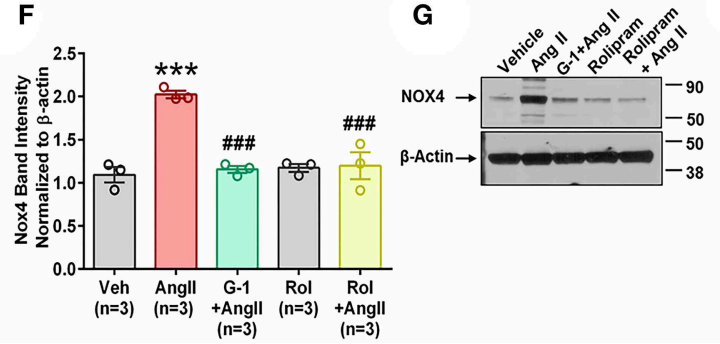

C

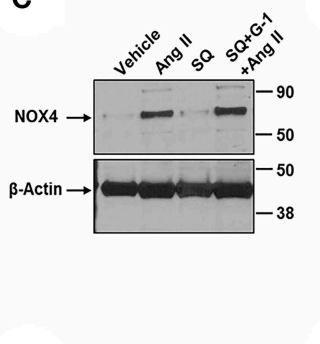

G

D

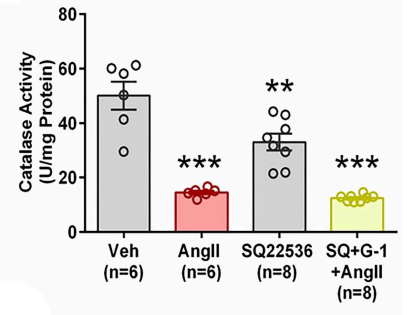

H

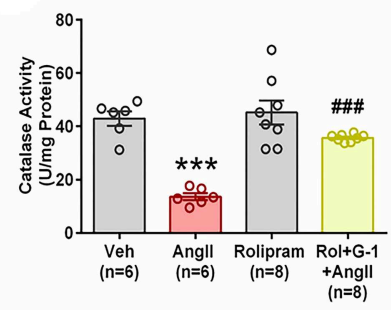

FIGURE 8 | Impact of CAMP signaling. The adenylyl cyclase inhibitor SQ22536 (SQ) blocked the ability of GPER to oppose the impact of Ang II on (A) NADP/NADPH ratio. 1-way ANOVA, $p<0.0001$, Tukey, ${ }^{\star \star \star} p<0.001$ vs. Veh, $\# \# \# p<0.001$ vs. Ang II. (B) Nox4 protein. 1 -way ANOVA, $p=0.0003$, Holm-Sidak, ${ }^{\star \star} p<0.01$ vs. Veh. (C) Representative blot for (B). (D) SQ also blocks G-1's ability to reverse Ang II-induced decreased catalase activity. 1-way ANOVA, $p<0.0001$, Tukey, ${ }^{\star \star} p<$ $0.01,{ }^{* \star *} p<0.001$ vs. Veh. Increasing CAMP with the phosphodiesterase inhibitor rolipram (Rol) mimics the impact of G-1 on (E) NADP/NADPH ratio. 1-way ANOVA, $p<0.0001$, Tukey, ${ }^{\star \star \star} p<0.001$ vs. Veh, $\# \# \# p<0.001$ vs. Ang II. (F) Nox4 protein. 1-way ANOVA, $p<0.0001$, Tukey, $\# \# \# p<0.001$ vs. Veh, $\# \# \# p<0.001$ vs. Ang II. (G) Representative blot for (E). (H) Ang II-induced decreased catalase activity is restored by Roland G-1. 1-way ANOVA, $p<0.0001$, Tukey, ${ }^{\star \star \star} p<0.001$ vs. Veh; \#\#\# $p<0.001$ vs. Ang II.

These studies indicate a connection between GPER, oxidative stress, and Nox4 in multiple cardiovascular tissues.

Our experiments using GPER ko and wt mice indicate that females with intact GPER signaling were protected from Ang II-induced increases in aortic Nox1 and Nox4. While the ability of Ang II to upregulate Nox1/2 and negatively impact cardiovascular health is well-established, the role of Nox4 is still debatable. Studies show both up and downregulation of Nox4 in response to Ang II (30, 57-60). Functionally, Nox4 induces VSMC hypertrophy, oxidation of lipids, and inactivation of nitric oxide $(23,29)$, but is required for VSMC differentiation (61) and protects endothelial cells during hypoxia (62). This conflicting data is also observed in Nox4 knockout mice, where Ang II-hypertension is not impacted but aortic wall thickness is increased (63). Nox4-induced endothelium derived hyperpolarizing factor mediates a decrease in blood pressure, suggesting a vasculoprotective role (64). While Nox4 promotes nitric oxide production during shear stress in endothelial cells, during aging Nox4 uncouples endothelial nitric oxide synthase and induces oxidative stress (65). Importantly for the increased pulse pressure and aortic remodeling observed in the current study, Nox4 is upregulated in aortic smooth muscle during aging and contributes to mitochondrial ROS and vascular stiffening (66). The same group recently showed that overexpression of mitochondrial Nox4 increases aortic smooth muscle cell stiffness and pulse wave velocity (67). Similarly, pharmacological inhibition of Nox4 using GKT137831 attenuates hypoxia-induced pulmonary artery remodeling (68), and a Nox4 dominant negative mutation protects atherosclerotic mice from increases in pulse wave velocity (69). Since GPER antagonism reduces aortic ROS in aged male mice and was associated with downregulation of Nox1 but not Nox4 (21), the role of Nox4 in the vasculature may be altered during the aging process.

Another factor may be the relative amounts of superoxide vs. $\mathrm{H}_{2} \mathrm{O}_{2}$ that are produced by the Nox4 enzyme, which may depend on cell type. Nox4 produces superoxide in neurons and rat aortic smooth muscle cells $(31,70)$, but $\mathrm{H}_{2} \mathrm{O}_{2}$ in endothelial cells (71). The protective vs. detrimental impact of $\mathrm{H}_{2} \mathrm{O}_{2}$ may also differ by cell type. In a tamoxifen-inducible endothelial Nox 4 knockout mouse model, $\mathrm{H}_{2} \mathrm{O}_{2}$ produced by Nox 4 increases angiogenesis after femoral artery ligation injury demonstrating a protective role (63). However, smooth muscle cell overexpression of catalase, which quenches $\mathrm{H}_{2} \mathrm{O}_{2}$, protects from Ang II-induced aortic remodeling (23). Our data indicates that in cultured vascular smooth muscle cells, catalase activity is reduced in the presence of Ang II and reversed by the GPER agonist G-1. Ang II most likely downregulates catalase activity by increasing superoxide which reacts with superoxide dismutase to form $\mathrm{H}_{2} \mathrm{O}_{2}$ (72).

Since most studies are performed only in male mice, sex differences in Nox4 expression or function may underlie its beneficial vs. detrimental vascular effects. In males, Nox4 is highly expressed in basilar cerebral arteries (73), while females express high Nox4 in mesenteric (74) and porcine coronary arteries (75), suggesting sex and functional differences. Sexual dimorphisms may also become important when considering GPER, since we found a trend for lower MAP and cardiac protection in Mko mice in the current study. Similarly, GPER 
antagonism in aging male mice confers protection from oxidative stress by decreasing vascular Nox1 with no impact on Nox4 (21). Nox1 and 4 may interact in the regulation of ROS since nonspecific Nox1/4 inhibitors GKT136901 or GKT137831 attenuate oxidative stress $(44,45,68)$. Our study indicates that in female mice infused with Ang II, Nox4 plays a detrimental role in vascular smooth muscle cell remodeling, while intact signaling by GPER confers protection.

Surprisingly, activation of a G protein-coupled receptor known for its role in acute estrogen signaling had a significant impact on Nox4 mRNA within $4 \mathrm{~h}$. Other GPCRs such as endothelin-1 and thrombin receptors also regulate NADPH oxidases (76). Our study also demonstrated that cAMP activation by GPER is necessary to regulate both NADP/NADPH ratio and Nox4 expression. Activation of GPER by the agonist G1 activates adenylyl cyclase, leading to accumulation of cAMP (77), and work from our lab and others show that this GPER signaling cascade induces vasorelaxation $(8,78)$. Downstream phosphorylation of protein kinase A activates cAMP response element binding protein (CREB), a transcription factor that regulates several genes including Nox1 and Nox5 (79, 80). Activation of the cAMP-CREB pathway attenuates VSMC migration (81), while reductions in cAMP increase NADP oxidation to promote ROS in aortic smooth muscle cells (31, 82). Our results connecting GPER-induced cAMP increases with Nox4 regulation and NADP/NADPH ratio indicate that this signaling pathway plays an important role in attenuating Ang II-induced oxidative stress and remodeling. Interestingly, Ang IIinduced downregulation of catalase activity can also be reversed by G-1 and rolipram, suggesting a distinct pathway involving the stimulation of adenylyl cyclase and accumulation of cAMP for protection against Ang II-induced ROS.

In addition to the current findings, activation of GPER attenuates oxidative damage to pancreatic beta cells in diabetes (47) and protects neurons from oxidative stress in the brain (83). Since oxidative stress is involved in many disease processes and GPER is ubiquitously distributed in mammals, therapeutic targeting of this estrogen receptor may provide benefits. While

\section{REFERENCES}

1. Garcia M, Mulvagh SL, Merz CN, Buring JE, Manson JE. Cardiovascular disease in women: clinical perspectives. Circ Res. (2016) 118:1273-93. doi: 10.1161/CIRCRESAHA.116.307547

2. Lindsey SH, Cohen JA, Brosnihan KB, Gallagher PE, Chappell MC. Chronic treatment with the G protein-coupled receptor 30 agonist G-1 decreases blood pressure in ovariectomized mRen2.Lewis rats. Endocrinology. (2009) 150:3753-8. doi: 10.1210/en.2008-1664

3. Lindsey SH, Carver KA, Prossnitz ER, Chappell MC. Vasodilation in response to the GPR30 agonist G-1 is not different from estradiol in the mRen2.Lewis female rat. J Cardiovasc Pharmacol. (2011) 57:598-603. doi: 10.1097/FJC.0b013e3182135f1c

4. Gros R, Ding Q, Sklar LA, Prossnitz EE, Arterburn JB, Chorazyczewski J, et al. GPR30 expression is required for the mineralocorticoid receptorindependent rapid vascular effects of aldosterone. Hypertension. (2011) 57:442-51. doi: 10.1161/HYPERTENSIONAHA.110.161653

5. Ogola B, Zhang Y, Iyer L, Thekkumkara T. 2-Methoxyestradiol causes MMP 9 mediated transactivation of EGFR and angiotensin type 1 receptor menopause is associated with an increase in cardiovascular disease, vascular stiffening, and increased ROS production (84), GPER may have the capacity to selectively decrease oxidative stress without activating nuclear estrogenic signaling. Therefore, inclusion of GPER as a therapeutic target may alleviate deleterious effects in both cardiovascular and metabolic diseases.

\section{DATA AVAILABILITY}

The datasets generated during the current study are available in the Harvard Dataverse repository: https://dataverse.harvard.edu/ dataset.xhtml?persistentId=doi:10.7910/DVN/Z9FEPX.

\section{ETHICS STATEMENT}

All procedures were carried out in accordance with the NIH Guide for the Care and Use of Laboratory Animals and approved by the Tulane University Institutional Animal Care and Use Committee.

\section{AUTHOR CONTRIBUTIONS}

$\mathrm{BO}, \mathrm{KM}, \mathrm{PK}$, and SL contributed conception and design of the study. BO, VS, JD, KG, MZ, and GC performed the experiments. $\mathrm{BO}$ and SL performed the statistical analysis. BO wrote the first draft of the manuscript. SL wrote sections of the manuscript. All authors contributed to manuscript revisions and approved the submitted version.

\section{FUNDING}

This work was supported by National Institutes of Health grant numbers HL133619 to SL and NS094834 to PK.

\section{ACKNOWLEDGMENTS}

We are grateful for the expert and technical assistance of Sufen Zhang in performing electron spin resonance experiments. downregulation in rat aortic smooth muscle cells. Am J Physiol Cell Physiol. (2018) 314:C554-68. doi: 10.1152/ajpcell.00152.2017

6. Surico D, Ercoli A, Farruggio S, Raina G, Filippini D, Mary D, et al. Modulation of oxidative stress by $17 \beta$-estradiol and genistein in human hepatic cell lines in vitro. Cell Physiol Biochem. (2017) 42:1051-62. doi: $10.1159 / 000478752$

7. Bologa CG, Revankar CM, Young SM, Edwards BS, Arterburn JB, Kiselyov AS, et al. Virtual and biomolecular screening converge on a selective agonist for GPR30. Nat Chem Biol. (2006) 2:207-12. doi: 10.1038/nchemb io775

8. Lindsey SH, Liu L, Chappell MC. Vasodilation by GPER in mesenteric arteries involves both endothelial nitric oxide and smooth muscle cAMP signaling. Steroids. (2014) 81:99-102. doi: 10.1016/j.steroids.2013.10.017

9. Liu L, Kashyap S, Murphy B, Hutson DD, Budish RA, Trimmer EH, et al. GPER activation ameliorates aortic remodeling induced by saltsensitive hypertension. Am J Physiol Heart Circ Physiol. (2016) 310:H953-61. doi: 10.1152/ajpheart.00631.2015

10. Lindsey SH, Yamaleyeva LM, Brosnihan KB, Gallagher PE, Chappell MC. Estrogen receptor GPR30 reduces oxidative stress and proteinuria in the 
salt-sensitive female mRen2.Lewis rat. Hypertension. (2011) 58:665-71. doi: 10.1161/HYPERTENSIONAHA.111.175174

11. Wang H, Jessup JA, Lin MS, Chagas C, Lindsey SH, Groban L. Activation of GPR30 attenuates diastolic dysfunction and left ventricle remodelling in oophorectomized mRen2.Lewis rats. Cardiovasc Res. (2012) 94:96-104. doi: $10.1093 / \mathrm{cvr} / \mathrm{cvs} 090$

12. De Francesco EM, Rocca C, Scavello F, Amelio D, Pasqua T, Rigiracciolo DC, et al. Protective role of GPER agonist G-1 on cardiotoxicity induced by doxorubicin. J Cell Physiol. (2017) 232:1640-9. doi: 10.1002/jcp. 25585

13. Prossnitz ER, Hathaway HJ. What have we learned about GPER function in physiology and disease from knockout mice? J Steroid Biochem Mol Biol. (2015) 153:114-26. doi: 10.1016/j.jsbmb.2015.06.014

14. Davis KE, Carstens EJ, Irani BG, Gent LM, Hahner LM, Clegg DJ. Sexually dimorphic role of $G$ protein-coupled estrogen receptor (GPER) in modulating energy homeostasis. Hormones Behav. (2014) 66:196-207. doi: 10.1016/j.yhbeh.2014.02.004

15. Haas E, Bhattacharya I, Brailoiu E, Damjanovic M, Brailoiu GC, Gao X, et al. Regulatory role of $G$ protein-coupled estrogen receptor for vascular function and obesity. Circ Res. (2009) 104:288-91. doi: 10.1161/CIRCRESAHA.108.190892

16. Meyer MR, Fredette NC, Howard TA, Hu C, Ramesh C, Daniel C, et al. $\mathrm{G}$ protein-coupled estrogen receptor protects from atherosclerosis. Sci Rep. (2014) 4:7564. doi: 10.1038/srep07564

17. Martensson UE, Salehi SA, Windahl S, Gomez MF, Sward K, DaszkiewiczNilsson J, et al. Deletion of the $\mathrm{G}$ protein-coupled receptor 30 impairs glucose tolerance, reduces bone growth, increases blood pressure, and eliminates estradiol-stimulated insulin release in female mice. Endocrinology. (2009) 150:687-98. doi: 10.1210/en.2008-0623

18. Wang H, Sun X, Chou J, Lin M, Ferrario CM, Zapata-Sudo G, et al, Cardiomyocyte-specific deletion of the $\mathrm{G}$ protein-coupled estrogen receptor (GPER) leads to left ventricular dysfunction and adverse remodeling: a sexspecific gene profiling analysis. Biochim Biophys Acta. (2017) 1863:1870-82. doi: 10.1016/j.bbadis.2016.10.003

19. Lindsey SH, da Silva AS, Silva MS, Chappell MC. Reduced vasorelaxation to estradiol and G-1 in aged female and adult male rats is associated with GPR30 downregulation. Am J Physiol Endocrinol Metab. (2013) 305:E113E118. doi: 10.1152/ajpendo.00649.2012

20. Peixoto P, da Silva JF, Aires RD, Costa ED, Lemos VS, Bissoli NS, et al. Sex difference in GPER expression does not change vascular relaxation or reactive oxygen species generation in rat mesenteric resistance arteries. Life Sci. (2018) 211:198-205. doi: 10.1016/j.lfs.2018.09.036

21. Meyer MR, Fredette NC, Daniel C, Sharma G, Amann K, Arterburn JB, et al. Obligatory role for GPER in cardiovascular aging and disease. Sci Signal. (2016) 9:ra105. doi: 10.1126/scisignal.aag0240

22. Meyer MR, Rosemann T, Barton M, Prossnitz ER. GPER mediates functional endothelial aging in renal arteries. Pharmacology. (2017) 100:188-93. doi: $10.1159 / 000478732$

23. Zhang Y, Griendling KK, Dikalova A, Owens GK, Taylor WR. Vascular hypertrophy in angiotensin II-induced hypertension is mediated by vascular smooth muscle cell-derived $\mathrm{H}_{2} \mathrm{O}_{2}$. Hypertension. (2005) 46:732-7. doi: 10.1161/01.HYP.0000182660.74266.6d

24. Liu CF, Zhang J, Shen K, Gao PJ, Wang HY, Jin X, et al. Adventitial gene transfer of catalase attenuates angiotensin II-induced vascular remodeling. Mol Med Rep. (2015) 11:2608-14. doi: 10.3892/mmr.2014.3069

25. Touyz RM, Briones AM. Reactive oxygen species and vascular biology: implications in human hypertension. Hypertens Res. (2011) 34:5-14. doi: 10.1038/hr.2010.201

26. Chouchani ET, Pell VR, Gaude E, Aksentijević D, Sundier SY, Robb EL, et al. Ischaemic accumulation of succinate controls reperfusion injury through mitochondrial ROS. Nature. (2014) 515:431-5. doi: 10.1038/nature13909

27. Ambasta RK, Kumar P, Griendling KK, Schmidt HH, Busse R, Brandes RP. Direct interaction of the novel Nox proteins with p22phox is required for the formation of a functionally active NADPH oxidase. J Biol Chem. (2004) 279:45935-41. doi: 10.1074/jbc.M406486200

28. Lassegue B, San Martin A, Griendling KK. Biochemistry, physiology, and pathophysiology of NADPH oxidases in the cardiovascular system. Circ Res. (2012) 110:1364-90. doi: 10.1161/CIRCRESAHA.111.243972
29. Griendling KK, Minieri CA, Ollerenshaw JD, Alexander RW. Angiotensin II stimulates NADH and NADPH oxidase activity in cultured vascular smooth muscle cells. Circ Res. (1994) 74:1141-8. doi: 10.1161/01.RES.74.6.1141

30. Wingler K, Wünsch S, Kreutz R, Rothermund L, Paul M, Schmidt HH. Upregulation of the vascular NAD(P)H-oxidase isoforms Noxl and Nox4 by the renin-angiotensin system in vitro and in vivo. Free Radic Biol Med. (2001) 31:1456-64. doi: 10.1016/S0891-5849(01)00727-4

31. Saha S, Li Y, Anand-Srivastava MB. Reduced levels of cyclic AMP contribute to the enhanced oxidative stress in vascular smooth muscle cells from spontaneously hypertensive rats. Can J Physiol Pharmacol. (2008) 86:190-8. doi: 10.1139/Y08-012

32. Broughton BR, Miller AA, Sobey CG. Endothelium-dependent relaxation by G protein-coupled receptor 30 agonists in rat carotid arteries. Am J Physiol Heart Circ Physiol. (2010) 298:H1055-61. doi: 10.1152/ajpheart.00878.2009

33. Wang H, Sun X, Lin MS, Ferrario CM, Van Remmen H, Groban L. G protein-coupled estrogen receptor (GPER) deficiency induces cardiac remodeling through oxidative stress. Transl Res. (2018) 199:39-51. doi: 10.1016/j.trsl.2018.04.005

34. Wang C, Dehghani B, Magrisso IJ, Rick EA, Bonhomme E, Cody DB, et al. GPR30 contributes to estrogen-induced thymic atrophy. Mol Endocrinol. (2008) 22:636-48. doi: 10.1210/me.2007-0359

35. Zimmerman MA, Hutson DD, Mauvais-Jarvis F, Lindsey SH. Bazedoxifene-induced vasodilation and inhibition of vasoconstriction is significantly greater than estradiol. Menopause. (2018) 26:172-81. doi: 10.1097/GME.0000000000001195

36. Jennings BL, George LW, Pingili AK, Khan NS, Estes AM, Fang XR, et al. Estrogen metabolism by cytochrome P450 1B1 modulates the hypertensive effect of angiotensin II in female mice. Hypertension. (2014) 64:134-40. doi: 10.1161/HYPERTENSIONAHA.114.03275

37. Xue B, Pamidimukkala J, Hay M. Sex differences in the development of angiotensin II-induced hypertension in conscious mice. Am J Physiol Heart Circ Physiol. (2005) 288:H2177-84. doi: 10.1152/ajpheart.00969.2004

38. Dennis MK, Field AS, Burai R, Ramesh C, Petrie WK, Bologa CG, et al. Identification of a GPER/GPR30 antagonist with improved estrogen receptor counterselectivity. J Steroid Biochem Mol Biol. (2011) 127:358-66. doi: 10.1016/j.jsbmb.2011.07.002

39. Sun Q, Zhang W, Zhong W, Sun X, Zhou Z. Pharmacological inhibition of NOX4 ameliorates alcohol-induced liver injury in mice through improving oxidative stress and mitochondrial function. Biochim Biophys Acta Gen Subj. (2017) 1861:2912-21. doi: 10.1016/j.bbagen.2016.09.009

40. Katakam PV, Gordon AO, Sure VN, Rutkai I, Busija DW. Diversity of mitochondria-dependent dilator mechanisms in vascular smooth muscle of cerebral arteries from normal and insulin-resistant rats. Am J Physiol Heart Circ Physiol. (2014) 307:H493-503. doi: 10.1152/ajpheart.00091.2014

41. Vivekananthan DP, Penn MS, Sapp SK, Hsu A, Topol EJ. Use of antioxidant vitamins for the prevention of cardiovascular disease: meta-analysis of randomised trials. Lancet. (2003) 361:2017-23. doi: 10.1016/S0140-6736(03)13637-9

42. Miller ER III, Pastor-Barriuso R, Dalal D, Riemersma RA, Appel LJ, Guallar E. Meta-analysis: high-dosage vitamin E supplementation may increase all-cause mortality. Ann Intern Med. (2005) 142:37-46. doi: 10.7326/0003-4819-142-1-200501040-00110

43. Bjelakovic G, Nikolova D, Gluud LL, Simonetti RG, Gluud C. Mortality in randomized trials of antioxidant supplements for primary and secondary prevention: systematic review and meta-analysis. JAMA. (2007) 297:842-57. doi: 10.1001/jama.297.8.842

44. Appukuttan B, Ma Y, Stempel A, Ashander LM, Deliyanti D, WilkinsonBerka JL, et al. Effect of NADPH oxidase 1 and 4 blockade in activated human retinal endothelial cells. Clin Exp Ophthalmol. (2018) 46:652-60. doi: $10.1111 /$ ceo. 13155

45. Gray SP, Jha JC, Kennedy K, van Bommel E, Chew P, Szyndralewiez C, et al. Combined NOX1/4 inhibition with GKT137831 in mice provides dose-dependent reno- and atheroprotection even in established micro- and macrovascular disease. Diabetologia. (2017) 60:927-37. doi: $10.1007 / \mathrm{s} 00125-017-4215-5$

46. Wilde E, Aubdool AA, Thakore P, Baldissera L Jr, Alawi KM, Keeble J, et al. Tail-Cuff technique and its influence on central blood pressure in the mouse. J Am Heart Assoc. (2017) 6:e005204. doi: 10.1161/JAHA.116.005204 
47. Liu S, Le May C, Wong WP, Ward RD, Clegg DJ, Marcelli M, et al. Importance of extranuclear estrogen receptor-alpha and membrane $\mathrm{G}$ protein-coupled estrogen receptor in pancreatic islet survival. Diabetes. (2009) 58:2292-302. doi: $10.2337 / \mathrm{db} 09-0257$

48. Hartner A, Cordasic N, Klanke B, Veelken R, Hilgers KF. Strain differences in the development of hypertension and glomerular lesions induced by deoxycorticosterone acetate salt in mice. Nephrol Dial Transplant. (2003) 18:1999-2004. doi: 10.1093/ndt/gfg299

49. Lum C, Shesely EG, Potter DL, Beierwaltes WH. Cardiovascular and renal phenotype in mice with one or two renin genes. Hypertension. (2004) 43:7986. doi: 10.1161/01.HYP.0000107401.72456.50

50. Avolio AP, Kuznetsova T, Heyndrickx GR, Kerkhof PLM, Li JK. Arterial flow, pulse pressure and pulse wave velocity in men and women at various ages. Adv Exp Med Biol. (2018) 1065:153-68. doi: 10.1007/978-3-319-77932-4_10

51. Protogerou AD, Vlachopoulos C, Thomas F, Zhang Y, Pannier B, Blacher J, et al. Longitudinal changes in mean and pulse pressure, and all-cause mortality: data from 71,629 untreated normotensive individuals. Am J Hypertens. (2017) 30:1093-99. doi: 10.1093/ajh/hpx110

52. Weisbrod RM, Shiang T, Al Sayah L, Fry JL, Bajpai S, ReinhartKing CA, et al. Arterial stiffening precedes systolic hypertension in diet-induced obesity. Hypertension. (2013) 62:1105-10. doi: 10.1161/HYPERTENSIONAHA.113.01744

53. Zhang L, Zhu C, Zhang X, Wan Y, Song J. Dual effects of estrogen on vascular smooth muscle cells: receptor-mediated proliferative vs. metabolite-induced pro-senescent actions. Steroids. (2011) 76:309-16. doi: 10.1016/j.steroids.2010.12.002

54. Bopassa JC, Eghbali M, Toro L, Stefani E. A novel estrogen receptor GPER inhibits mitochondria permeability transition pore opening and protects the heart against ischemia-reperfusion injury. Am J Physiol Heart Circ Physiol. (2010) 298:H16-23. doi: 10.1152/ajpheart.00588.2009

55. Kurt AH, Bozkus F, Uremis N, Uremis MM. The protective role of G protein-coupled estrogen receptor 1 (GPER-1) on methotrexate-induced nephrotoxicity in human renal epithelium cells. Ren Fail. (2016) 38:686-92. doi: 10.3109/0886022X.2016.1155398

56. Kuroda J, Ago T, Matsushima S, Zhai P, Schneider MD, Sadoshima J. NADPH oxidase 4 (Nox4) is a major source of oxidative stress in the failing heart. Proc Natl Acad Sci USA. (2010) 107:15565-70. doi: 10.1073/pnas.10021 78107

57. Higashi M, Shimokawa H, Hattori T, Hiroki J, Mukai Y, Morikawa $\mathrm{K}$, et al. Long-term inhibition of Rho-kinase suppresses angiotensin II-induced cardiovascular hypertrophy in rats in vivo: effect on endothelial NAD(P)H oxidase system. Circ Res. (2003) 93:767-75. doi: 10.1161/01.RES.0000096650.91688.28

58. Yamagishi S, Nakamura K, Ueda S, Kato S, Imaizumi T. Pigment epitheliumderived factor (PEDF) blocks angiotensin II signaling in endothelial cells via suppression of NADPH oxidase: a novel anti-oxidative mechanism of PEDF. Cell Tissue Res. (2005) 320:437-45. doi: 10.1007/s00441-005-1094-8

59. Zeng SY, Chen X, Chen SR, Li Q, Wang YH, Zou J, et al. Upregulation of Nox4 promotes angiotensin II-induced epidermal growth factor receptor activation and subsequent cardiac hypertrophy by increasing ADAM17 expression. Can J Cardiol. (2013) 29:1310-9. doi: 10.1016/j.cjca.2013.04.026

60. Lassegue B, Sorescu D, Szocs K, Yin Q, Akers M, Zhang Y, et al. Novel gp91(phox) homologues in vascular smooth muscle cells: nox1 mediates angiotensin II-induced superoxide formation and redox-sensitive signaling pathways. Circ Res. (2001) 88:888-94. doi: 10.1161/hh0901.090299

61. Clempus RE, Sorescu D, Dikalova AE, Pounkova L, Jo P, Sorescu GP, et al. Nox 4 is required for maintenance of the differentiated vascular smooth muscle cell phenotype. Arterioscler Thromb Vasc Biol. (2007) 27:42-8. doi: 10.1161/01.ATV.0000251500.94478.18

62. Craige SM, Chen K, Pei Y, Li C, Huang X, Chen C, et al. NADPH oxidase 4 promotes endothelial angiogenesis through endothelial nitric oxide synthase activation. Circulation. (2011) 124:731-40. doi: 10.1161/CIRCULATIONAHA.111.030775

63. Schroder K, Zhang M, Benkhoff S, Mieth A, Pliquett R, Kosowski J, et al. Nox4 is a protective reactive oxygen species generating vascular NADPH oxidase. Circ Res. (2012) 110:1217-25. doi: 10.1161/CIRCRESAHA.112.267054

64. Ray R, Murdoch CE, Wang M, Santos CX, Zhang M, Alom-Ruiz S, et al. Endothelial Nox4 NADPH oxidase enhances vasodilatation and reduces blood pressure in vivo. Arterioscler Thromb Vasc Biol. (2011) 31:1368-76. doi: 10.1161/ATVBAHA.110.219238

65. Lee HY, Zeeshan HMA, Kim HR, Chae HJ. Nox4 regulates the eNOS uncoupling process in aging endothelial cells. Free Radic Biol Med. (2017) 113:26-35. doi: 10.1016/j.freeradbiomed.2017.09.010

66. Vendrov AE, Vendrov KC, Smith A, Yuan J, Sumida A, Robidoux J, et al. NOX4 NADPH oxidase-dependent mitochondrial oxidative stress in agingassociated cardiovascular disease. Antioxid Redox Signal. (2015) 23:1389-409. doi: 10.1089/ars.2014.6221

67. Canugovi C, Stevenson MD, Vendrova AE, Hayami T, Robidoux J, Xiao $\mathrm{H}$, et al. Increased mitochondrial NADPH oxidase 4 (NOX4) expression in aging is a causative factor in aortic stiffening. Redox Biol. (2019) 2019:01288. doi: 10.1016/j.redox.2019.101288

68. Green DE, Murphy TC, Kang BY, Kleinhenz JM, Szyndralewiez C, Page P, et al. The Nox4 inhibitor GKT137831 attenuates hypoxia-induced pulmonary vascular cell proliferation. Am J Respir Cell Mol Biol. (2012) 47:718-26. doi: 10.1165/rcmb.2011-04180C

69. Tong X, Khandelwal AR, Wu X, Xu Z, Yu W, Chen C, et al. Pro-atherogenic role of smooth muscle Nox4-based NADPH oxidase. J Mol Cell Cardiol. (2016) 92:30-40. doi: 10.1016/j.yjmcc.2016.01.020

70. Case AJ, Li S, Basu U, Tian J, Zimmerman MC. Mitochondriallocalized NADPH oxidase 4 is a source of superoxide in angiotensin IIstimulated neurons. Am J Physiol Heart Circ Physiol. (2013) 305:H19-28. doi: 10.1152/ajpheart.00974.2012

71. Sanchez-Gomez FJ, Calvo E, Breton-Romero R, Fierro-Fernandez M, Anilkumar N, Shah AM, et al. NOX4-dependent hydrogen peroxide promotes shear stress-induced SHP2 sulfenylation and eNOS activation. Free Radic Biol Med. (2015) 89:419-30. doi: 10.1016/j.freeradbiomed.2015.08.014

72. Yang W, Zhang J, Wang H, Gao P, Singh M, Shen K, et al. Angiotensin II downregulates catalase expression and activity in vascular adventitial fibroblasts through an AT1R/ERK1/2-dependent pathway. Mol Cell Biochem. (2011) 358:21-9. doi: 10.1007/s11010-011-0915-1

73. Miller AA, Drummond GR, Mast AE, Schmidt HH, Sobey CG. Effect of gender on NADPH-oxidase activity, expression, and function in the cerebral circulation: role of estrogen. Stroke. (2007) 38:2142-9. doi: 10.1161/STROKEAHA.106.477406

74. Zhang R, Thor D, Han X, Anderson L, Rahimian R. Sex differences in mesenteric endothelial function of streptozotocin-induced diabetic rats: a shift in the relative importance of EDRFs. Am J Physiol Heart Circ Physiol. (2012) 303:H1183-98. doi: 10.1152/ajpheart.00327.2012

75. Wong PS, Randall MD, Roberts RE. Sex differences in the role of $\mathrm{NADPH}$ oxidases in endothelium-dependent vasorelaxation in porcine isolated coronary arteries. Vasc Pharmacol. (2015) 72:83-92. doi: 10.1016/j.vph.2015.04.001

76. Taylor CJ, Weston RM, Dusting GJ, Roulston CL. NADPH oxidase and angiogenesis following endothelin-1 induced stroke in rats: role for nox2 in brain repair. Brain Sci. (2013) 3:294-317. doi: 10.3390/brainsci3010294

77. Thomas P, Pang Y, Filardo EJ, Dong J. Identity of an estrogen membrane receptor coupled to a $\mathrm{G}$ protein in human breast cancer cells. Endocrinology. (2005) 146:624-32. doi: 10.1210/en.2004-1064

78. Yu X, Li F, Klussmann E, Stallone JN, Han G. G protein-coupled estrogen receptor 1 mediates relaxation of coronary arteries via cAMP/PKA-dependent activation of MLCP. Am J Physiol Endocrinol Metab. (2014) 307:E398-407. doi: 10.1152/ajpendo.00534.2013

79. Shimizu H, Saito S, Higashiyama Y, Nishijima F, Niwa T. CREB, NF$\kappa \mathrm{B}$, and NADPH oxidase coordinately upregulate indoxyl sulfate-induced angiotensinogen expression in proximal tubular cells. Am J Physiol Cell Physiol. (2013) 304:C685-92. doi: 10.1152/ajpcell.00236.2012

80. Fu X, Beer DG, Behar J, Wands J, Lambeth D, Cao W. cAMP-response element-binding protein mediates acid-induced NADPH oxidase NOX5-S expression in Barrett esophageal adenocarcinoma cells. J Biol Chem. (2006) 281:20368-82. doi: 10.1074/jbc.M603353200

81. McKean JS, Murray F, Gibson G, Shewan DA, Tucker SJ, Nixon GF. The cAMP-producing agonist beraprost inhibits human vascular smooth muscle cell migration via exchange protein directly activated by cAMP. Cardiovasc Res. (2015) 107:546-55. doi: 10.1093/cvr/cvv176

82. Zalba G, Beaumont FJ, San José G, Fortuño A, Fortuño MA, Etayo JC, et al. Vascular NADH/NADPH oxidase is involved in enhanced superoxide 
production in spontaneously hypertensive rats. Hypertension. (2000) 35:105561. doi: 10.1161/01.HYP.35.5.1055

83. Altmann JB, Yan G, Meeks JF, Abood ME, Brailoiu E, Brailoiu GC. G protein-coupled estrogen receptor-mediated effects on cytosolic calcium and nanomechanics in brain microvascular endothelial cells. J Neurochem. (2015) 133:629-39. doi: 10.1111/jnc. 13066

84. Sanchez-Rodriguez MA, Zacarias-Flores M, Arronte-Rosales A, CorreaMunoz E, Mendoza-Nunez VM. Menopause as risk factor for oxidative stress. Menopause. (2012) 19:361-7. doi: 10.1097/gme.0b013e31822 $9977 \mathrm{~d}$
Conflict of Interest Statement: The authors declare that the research was conducted in the absence of any commercial or financial relationships that could be construed as a potential conflict of interest.

Copyright $\odot 2019$ Ogola, Zimmerman, Sure, Gentry, Duong, Clark, Miller, Katakam and Lindsey. This is an open-access article distributed under the terms of the Creative Commons Attribution License (CC BY). The use, distribution or reproduction in other forums is permitted, provided the original author(s) and the copyright owner(s) are credited and that the original publication in this journal is cited, in accordance with accepted academic practice. No use, distribution or reproduction is permitted which does not comply with these terms. 